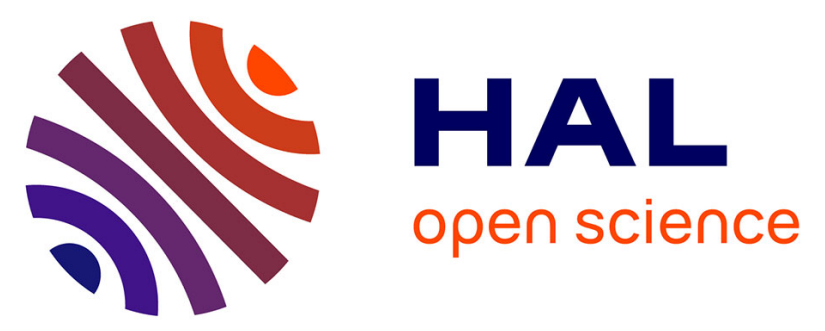

\title{
Dam-associated multiple-stressor impacts on fungal biomass and richness reveal the initial signs of ecosystem functioning impairment
}

Fanny Colas, Jean-Marc Baudoin, Eric Chauvet, Hugues Clivot, Michael Danger, François Guérold, Simon Devin

\section{To cite this version:}

Fanny Colas, Jean-Marc Baudoin, Eric Chauvet, Hugues Clivot, Michael Danger, et al.. Damassociated multiple-stressor impacts on fungal biomass and richness reveal the initial signs of ecosystem functioning impairment. Ecological Indicators, 2016, vol. 60, pp. 1077-1090. 10.1016/j.ecolind.2015.08.027 . hal-01281925

\section{HAL Id: hal-01281925 \\ https://hal.science/hal-01281925}

Submitted on 3 Mar 2016

HAL is a multi-disciplinary open access archive for the deposit and dissemination of scientific research documents, whether they are published or not. The documents may come from teaching and research institutions in France or abroad, or from public or private research centers.
L'archive ouverte pluridisciplinaire HAL, est destinée au dépôt et à la diffusion de documents scientifiques de niveau recherche, publiés ou non, émanant des établissements d'enseignement et de recherche français ou étrangers, des laboratoires publics ou privés. 


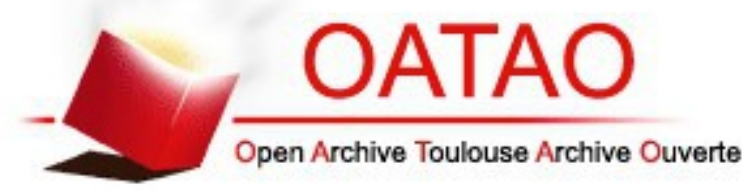

\section{Open Archive TOULOUSE Archive Ouverte (OATAO)}

OATAO is an open access repository that collects the work of Toulouse researchers and makes it freely available over the web where possible.

This is an author-deposited version published in : http://oatao.univ-toulouse.fr/ Eprints ID : 15521

To link to this article : DOI :10.1016/j.ecolind.2015.08.027

URL : http://dx.doi.org/10.1016/j.ecolind.2015.08.027

To cite this version : Colas, Fanny and Baudoin, Jean-Marc and Chauvet, Eric and Clivot, Hugues and Danger, Michael and Guérold, François and Devin, Simon Dam-associated multiple-stressor impacts on fungal biomass and richness reveal the initial signs of ecosystem functioning impairment. (2016) Ecological Indicators, vol. 60. pp. 1077-1090. ISSN 1470-160X

Any correspondance concerning this service should be sent to the repository administrator: staff-oatao@listes-diff.inp-toulouse.fr 


\title{
Dam-associated multiple-stressor impacts on fungal biomass and richness reveal the initial signs of ecosystem functioning impairment
}

\author{
Fanny Colas ${ }^{\mathrm{a}, \mathrm{b}, *}$, Jean-Marc Baudoin ${ }^{\mathrm{c}, 1}$, Eric Chauvet ${ }^{\mathrm{a}, \mathrm{b}, 2}$, Hugues Clivot $^{\mathrm{d}, 3}$, \\ Michael Danger $^{\mathrm{d}, 4}$, François Guérold $^{\mathrm{d}, 5}{ }$, Simon Devin ${ }^{\mathrm{d}, 6}$ \\ a Université de Toulouse, INP, UPS, EcoLab, 118 Route de Narbonne, 31062 Toulouse, France \\ b CNRS, EcoLab, 31062 Toulouse, France \\ ' Pôle d'Etudes et Recherches Hydro-écologie des Plans d'eau, Unité Hydrobiologie HYAX, Aix-en-Provence 13182, France \\ d Université de Lorraine, Laboratoire Interdisciplinaire des Environments Continentaux (LIEC) CNRS UMR 7360, Metz 57070, France
}

\begin{abstract}
A B S T R A C T
Global biodiversity is decreasing as a consequence of environmental changes and freshwater ecosystems are among the most threatened. There is an urgent need to identify indicators that are both sensitive to anthropogenic disturbances and predictive of the consequences of biodiversity changes on ecosystem functioning. The fungal compartment associated with decaying leaves is an excellent candidate for this purpose, given its key role in leaf litter breakdown, a major ecosystem process. In this study, we determined the extent to which microbial richness and biomass associated with leaf-decaying leaves could be used to predict impacts of multiple disturbances on ecosystem functioning using dams as models of multi-stressed (i.e. physically and chemically) ecosystems.

We conducted in situ and laboratory experiments to assess the response of the microbial compartment associated with decaying leaf litter to multiple stressors associated with dams and consequences on higher trophic levels. First, fungal biomass and taxa richness of communities associated with decaying alder leaf litter were determined at nine field sites. Second, two experiments under laboratory conditions were conducted with conditioned leaves from the field experiment to assess consequences of fungal changes on (1) their direct contribution to leaf litter breakdown by measuring the production of fine particulate organic matter (FPOM), and (2) leaf litter breakdown by two leaf-shredding invertebrates, Gammarus pulex and Allogamus auricollis, by measuring leaf consumption rates and FPOM production.

In the absence of contamination, the presence of a dam reduced fungal biomass in reservoirs and downstream reaches. Contaminated sediments significantly affected fungal biomass and taxa richness in reservoirs and appeared to lead to synergistic impacts further downstream. Laboratory experiments evidenced the cascading effects on their contribution to ecosystem functioning (i.e. directly by modifying their performance to breakdown leaf litter and indirectly by modifying shredder performance).

This study highlights the sensitivity of fungal-based indicators and their value for aquatic ecosystem bioassessment methodologies, identifying the effects of multiple stressors and reflecting the initial signs of ecosystem functioning impairment. Given the importance of the fate of organic matter stored within reservoirs for ecosystems downstream, the microbial compartment associated with decaying leaves could provide powerful indicators of the integrity of reservoir functioning, with strong potential for use in the
\end{abstract} risk assessment of multiple stressors associated with dams.

* Corresponding author at: Université de Toulouse, INP, UPS, EcoLab, 118 Route de Narbonne, 31062 Toulouse, France. Tel.: +33 0561558914.

E-mail addresses: fanny.colas@univ-tlse3.fr(F. Colas),jean-marc.baudoin@irstea.fr(J.-M. Baudoin), eric.chauvet@univ-tlse3.fr(E. Chauvet), hugues.clivot@univ-lorraine.fr

(H. Clivot), michael.danger@univ-lorraine.fr (M. Danger), francois.guerold@univ-lorraine.fr (F. Guérold), simon.devin@univ-lorraine.fr (S. Devin).

1 Tel.: +3304 42666970 .

2 Tel.: +330561558913.

3 Tel.: +330387378657.

4 Tel.: +330387378619.

5 Tel.: +330387378416.

6 Tel.: +330387378402. 


\section{Introduction}

Human societies are highly dependent on services provided by freshwater ecosystems, including water, food and energy (Millennium Ecosystem Assessment, 2005). Aquatic ecosystems are subjected to multiple disturbances, such as pollution, habitat degradation and flow regulation, and to their combined effects, leading to a high proportion of freshwater species currently at risk of extinction (Butchart et al., 2010; Dudgeon, 2010). The predicted growth in the human population worldwide, combined with modifications of environmental features related to global climate change, is more likely to lead to an increase in water needs and uses. Such increasing demands in conjunction with existing alterations (e.g. physical and chemical disturbances) will exacerbate the loss of biodiversity and in turn endanger the sustainability of the ecosystem services that freshwater systems provide (Vitousek et al., 1997). To understand and address the effects of biodiversity loss on ecosystem services provided by aquatic ecosystems, there is now an urgent need to identify both early (i.e. detecting first signs of alteration) and predictive (i.e. identifying effects on ecosystem functioning and on provision of ecosystem services) indicators of biodiversity loss. Most bioassessment tools are based on structural indicators that reflect community attributes, such as taxonomical composition (Birk et al., 2012). Even if these tools are widely recognised as being useful in a management context, they only partially highlight specific changes in ecosystem functioning (Sandin and Solimini, 2009). Conversely, functional indicators are usually associated with the direct measure of key ecosystem processes, such as leaf litter breakdown or primary production (Elosegi and Sabater, 2012). Despite their direct link with ecosystem functioning, such indicators remain little studied and are rarely integrated in a bioassessment context. Yet, identifying early and predictive indicators requires the joint study of the structure and function of ecosystems (Gessner and Chauvet, 2002; Palmer and Febria, 2012). Such identification would enable better understanding of the linkages between biodiversity and ecosystem function and, thus, the identification of thresholds beyond which the effects of disturbance on communities will impact ecosystem functioning (Hooper et al., 2005; Woodward et al., 2012). Functional indicators coming from these linkages would allow scientists to predict the first signs of alterations in ecosystem functioning, while being easy to integrate in current biomonitoring methodologies.

Leaf litter breakdown is an excellent candidate for an indicator of ecosystem functioning. Indeed, it is a key process in stream and river ecosystems, and there is a good understanding of the associated abiotic and biotic mechanisms and how they are affected by anthropogenic disturbances (e.g. Gessner and Chauvet, 2002; Dangles et al., 2004; Young et al., 2008). Allochthonous organic matter processing in aquatic ecosystems and its incorporation into trophic webs are mainly biological processes involving two types of organism: microorganisms [primarily fungi and typically aquatic hyphomycetes (Gessner et al., 2003; Weyers and Suberkropp, 1996)] and detritivore macroinvertebrates, which feed on coarse particulate organic matter. Although many biomonitoring tools focus on macroinvertebrates, aquatic hyphomycetes have an essential role in the functioning of aquatic ecosystems because of their pivotal contribution to the breakdown of allochthonous organic matter (Bärlocher, 1992, 2005; Suberkropp, 1998). Aquatic hyphomycetes are responsible for the initial breakdown of leaves, which they achieve through a variety of extracellular enzymes that attack the structural polysaccharides of plant-litter cell walls, releasing fine particulate matter consumed by collectors and inorganic and organic nutrients used by autotrophic and other heterotrophic organisms (Clivot et al., 2013; Mineau et al., 2013). The fungal colonisation of leaves also enhances their nutritional value and palatability to shredding invertebrates (e.g. Gammarus pulex) as a result of the mycelial biomass and enzymatic metabolisation of leaf tissue into more assimilable compounds (Rounick and Winterbourn, 1983; Graça et al., 1993, 2001; Canhoto et al., 2002). By increasing the quality of leaf detritus, aquatic hyphomycetes augment the conversion of leaf litter into fine particles and other decomposition products by shredders (Arsuffi and Suberkropp, 1989; Covich et al., 2004) and also influence the life-history traits of detritivores related to growth, survivorship and reproduction (Chung and Suberkropp, 2009). Consequently, changes in fungal growth and activity could lead to altered leaf litter breakdown and, therefore, energy and nutrient flow through the food chain (Greenwood et al., 2007). In particular, changes in the fungal conditioning of leaves might occur before decreases in leaf breakdown rate can be detected; thus, the former could be used to help forecast the impairment of ecosystem functioning.

The potential use of aquatic hyphomycetes in freshwater ecosystems biomonitoring has already been documented elsewhere (Lecerf and Chauvet, 2008; Solé et al., 2008; Proia et al., 2012). Among indicators frequently proposed, mycelial biomass and fungal diversity have been commonly used to assess impacts of anthropogenic disturbances, particularly chemical ones, on fungal communities and activities (e.g. Baudoin et al., 2008; Fernandes et al., 2009; Flores et al., 2014; Niyogi et al., 2002; Pascoal et al., 2005). Traditionally, ergosterol determination, a molecule largely restricted to eumycetes, is used to estimate fungal biomass associated with decaying leaves (Gessner and Chauvet, 1993). It has been routinely used in many studies on leaf breakdown, including in aquatic environments. For fungal diversity, a commonly used approach is fungal species identification based on morphological analyses of conidia (asexual spores) observed under microscope, which vary among species. Given that such an approach requires a certain level of expertise, recently developed molecular methods have been proposed that enable investigation of fungal assemblages regardless of their life-history stage, including mycelia, which constitute the metabolically active part of the fungal biomass on leaves (Bärlocher, 2007; Krauss et al., 2011). Molecular fingerprinting of microbial assemblages, namely terminal restriction fragment length polymorphism analysis and denaturing gradient gel electrophoresis (DGGE), showed that traditional methods of investigating fungal communities underestimated fungal diversity on leaves (Nikolcheva et al., 2003; Nikolcheva and Bärlocher, 2004). Indeed, various studies using traditional methods of fungal identification that showed a loss of aquatic hyphomycete diversity under anthropogenic disturbance, concurrently used DGGE to estimate fungal richness on leaves and revealed contrasting phylotype richness (e.g. Duarte et al., 2008). Phylotype richness always exceeded that of sporulating aquatic hyphomycetes in these studies, confirming the underestimation of fungal diversity when assessed only by traditional methods.

Although physical disturbances (e.g. dam, channelisation or flow reduction) are widespread, studies on the effects of hydromorphological changes on microbial communities associated with decaying leaves are scarce (e.g. Laitung et al., 2002; Schlief and Mutz, 2011, 2009; Mendoza-Lera et al., 2012), particularly in a context of multiple stressors. Run-of-river reservoirs constitute interesting models of multi-stressed ecosystems (both physically and chemically). Indeed, the presence of a dam impairs drastically the hydromorphological features of streams by modifying flow, channel forms and dynamics (e.g. Petts, 1989; Nilsson et al., 2005; Dade et al., 2011). In addition, the presence of a dam disrupts sediment transport, leading to its accumulation within impoundments and a depletion of sediment load downstream. These accumulated sediments become a sink of historical contamination, because they have a strong adsorption capacity for pollutants and may constitute a diffuse source of contamination. Indeed, pollutants can be released from sediments into the water column over the long term 
in response to ambient chemistry variation, sediment resuspension, or climatic changes (Neal et al., 2005; Lafont et al., 2007; Byrne et al., 2010). Despite the ecological and ecotoxicological risks associated with dam presence, run-of-river reservoirs, particularly small systems (i.e. dam height less than $15 \mathrm{~m}$ ), have been little studied and are rarely integrated in the biomonitoring scheme of water agencies. In the European Union in particular, small run-of-river reservoirs are not integrated in the main objective of the European Water Framework Directive (WFD; 2000/60/EC), which is to achieve a 'good ecological status' for all waters. Yet, these systems are numerous. For example, more than 76292 run-of-river reservoirs have been identified in France alone by the French National Agency for Water and Aquatic Environments (ONEMA).

The study of the leaf litter breakdown process is crucial when considering dams that act as effective retention structures of organic matter in river networks (Vörösmarty et al., 2003). In particular, dam presence was thought to impair leaf litter breakdown in the reservoir and in the downstream reaches as a result of modifications of: (i) the availability and quality of detrital resources; and (ii) the assemblages (i.e. invertebrates and microorganisms) involved in leaf litter decomposition. As such, changes in fungi associated with decaying leaves and, consequently, changes in the organic matter quality have the potential to alter the storage, transformation and export of carbon (C) in detritus-based ecosystems. These changes in resource conditioning are likely to increase the storage of organic matter in reservoirs, leading to its depletion and the resulting stress for downstream ecosystems.

In this study, we specifically examined the effects of small dams (i.e. height of dam less than $15 \mathrm{~m}$ ) on fungal richness and biomass associated with decaying leaves in reservoirs and downstream. We also conducted laboratory experiments to determine the effects of fungal responses in leaf breakdown mediated by fungi and by two detritivore species. We hypothesised that: (i) fungal biomass and richness should be sensitive to disturbances associated with the dam presence, but will respond differently to physical and chemical stressors; and (ii) changes in fungal biomass and richness should predict the contribution of fungi and detritivores to leaf breakdown. Consequently, we postulated that the fungal compartment should provide a proxy of the vulnerability of the ecosystem that would be both sensitive to multiple stressors associated with dams and predictive of disturbance impacts on ecosystem functioning.

\section{Materials and methods}

\subsection{Study sites and experimental design}

Four small run-of-river reservoirs were selected along the watercourse of the Ain and Bienne rivers within the same European ecoregion (Fig. 1; Northern Jura-Prealps, France) in relation to their levels of sediment contamination. According to the French National Agency for Water and Aquatic Environments (ONEMA), the studied reservoirs are small (2-7 ha, volume of reservoirs from 35550 to $53400 \mathrm{~m}^{3}$, height of dam less than $15 \mathrm{~m}$ ) and result from weirs along the watercourse. For each reservoir, a stream site was selected 200-300 $\mathrm{m}$ downstream of dam (Do) to examine the cumulative impact of dam presence and contaminated sediment stored into the associated reservoirs. Samples of sediments using an Ekman grab (sampling depth $20-30 \mathrm{~cm}$ ) and water were collected in reservoirs and streams sites during the field campaign. In reservoirs, three samples were collected in the area where the accumulation of sediments was the most important. Samples were sieved, homogenised and kept cool until analysis (i.e. $4 \pm 1{ }^{\circ} \mathrm{C}$ ). Similarly, three samples were taken for stream sites in natural areas of sediment accumulation, mainly in pools or littoral habitats.
The physicochemical characteristics of the sediment and water samples were measured by a specialised laboratory (LDA26, Valence, France) according to international or national standards: for metals [ISO 11885 (Fe, Al, Mn, Zn); NF EN ISO 17294-2 (Cd, Cr, $\mathrm{Co}, \mathrm{Cu}, \mathrm{Ni}, \mathrm{Pb}, \mathrm{As}$ ) and NF EN $1483(\mathrm{Hg})]$ and for polyaromatic hydrocarbons (PAHs) and polychlorinated biphenyls (PCBs) (XP X33012 method). Concentrations of 11 metals, 8 PCBs and 10 PAHs were investigated in sediments. PCBs were always below their quantification limit ( $5 \mathrm{mg} \mathrm{kg} \mathrm{DM}^{-1}$ ). The level of sediment contamination in a given reservoir was defined according to its mean rank for each pollutant concentration expressed in $\mathrm{mol} \mathrm{g}^{-1}$ (Colas et al., 2014). A higher rank represented a higher contamination level. The selected systems represented a significant gradient of sediment contamination in metals and PAHs (Friedman' test $-P<0.001$ ), from the reference reservoir $(\operatorname{Re} 1)$ to the most contaminated reservoir $(\operatorname{Re} 4)$. A site upstream of the less-contaminated reservoir(Up1) was added in the experimental design to discriminate the physical impact from the effects of sediment contamination on both the reservoir (Re1) and downstream (Do1) assemblages. Table 1 summarises the main environmental characteristics of the study sites.

\subsection{Conditioning of leaves}

The evaluation of fungal biomass and richness associated with decaying leaves was performed using the leaf bag methodology (Graça et al., 2005). Alder [Alnus glutinosa (L.) Gaertn.] leaves were collected from trees just before abscission, in autumn 2010. Leaf bags were made by enclosing $2 \mathrm{~g}( \pm 0.02)$ of air-dried leaves into mesh bags $(15 \mathrm{~cm} \times 20 \mathrm{~cm}, 500 \mu \mathrm{m}$ mesh size). At each site, an iron bar was anchored in a littoral habitat and nine bags were fastened to each bar and immersed during the 2010 winter field campaign. Three replicate bags were retrieved from the nine sites after 14, 28 and 45 days of exposure, immediately placed in individual sealed plastic bags with river water, and then transported to the laboratory in a cool box. At each sampling date, $2 \mathrm{~L}$ of water from each site was collected for laboratory processing of the leaf bags (leaf cleaning and incubation).

\subsection{Fungal biomass and molecular richness}

Ergosterol was used as an indicator of fungal biomass. At each sampling occasion, three replicate sets of five discs were cut from the leaves ( $\varnothing 12 \mathrm{~mm}$ ) and lyophilised. They were then weighed to the nearest $0.1 \mathrm{mg}$ and heated in $5 \mathrm{~mL}$ of alkaline methanol $(\mathrm{KOH}$, $8 \mathrm{~g} \mathrm{~L}^{-1}$ ) for $30 \mathrm{~min}$ at $80^{\circ} \mathrm{C}$. The extract was purified by solid-phase extraction on cartridges (Waters Oasis HLB, $60 \mathrm{mg}, \mathrm{cm}^{3}$ ). Ergosterol was separated by reversed phase high performance liquid chromatography (HPLC) on C18 and quantified by measuring the absorbance at $282 \mathrm{~nm}$. Ergosterol was converted to fungal biomass using a conversion factor of $5.5 \mathrm{mg}$ ergosterol $\mathrm{g}^{-1}$ mycelial dry mass (Gessner and Chauvet, 1993).

A DNA extraction and a PCR-DGGE analysis were used to analyse fungal assemblages. For DNA extraction, $100 \mathrm{mg}$ of leaf tissue from each replicate, site and exposure time were crushed and total DNA was extracted using the PowerSoil DNA Isolation Kit (MO BIO Laboratories, Carlsbad, CA). ITS3GC and ITS4 primers were used for PCR amplification of the ITS2 region of fungal ribosomal DNA (Nikolcheva and Bärlocher, 2005). The amplification products were separated with the DCODE Mutation Detection System (Bio-Rad, Hercules, CA). Electrophoresis was performed on $8 \%$ polyacrylamide gels with a denaturing gradient from 30 to $70 \%$ [100\% denaturant corresponds to $40 \%(\mathrm{v} / \mathrm{v})$ formamide and $7 \mathrm{M}$ urea]. DGGE were run for $16 \mathrm{~h}$ at $55 \mathrm{~V}$ and $56^{\circ} \mathrm{C}$ and stained with SYBR Green I. The gels were imaged with a STARION FLA-9000 scanner (Fujifilm Life Sciences FSVT, Courbevoie, France) and analysed using GelCompar II (Applied Maths, Sint-Martens-Latem, Belgium). DGGE 


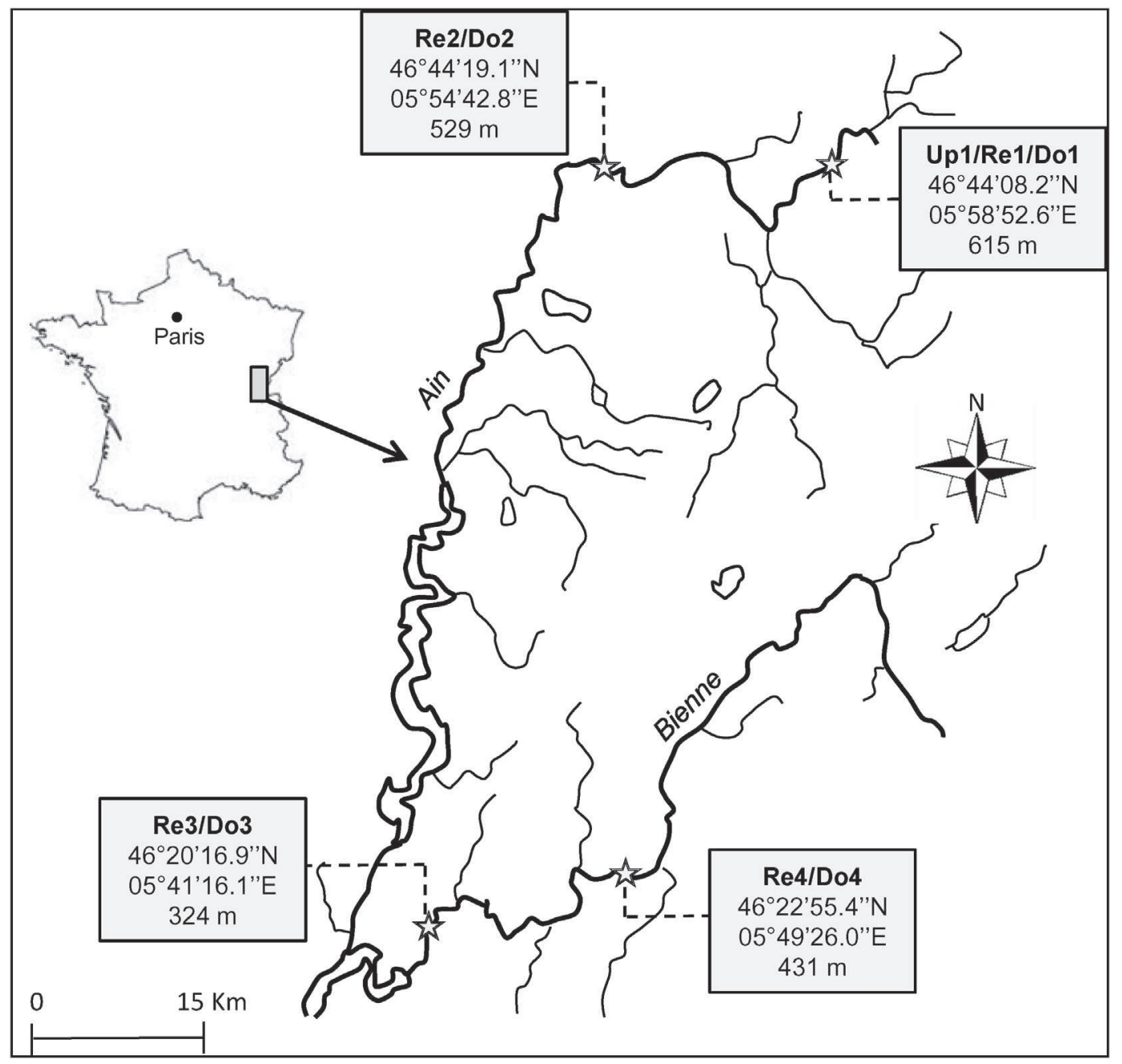

Fig. 1. Location of the study systems in the Jura Mountains, eastern France. Re, Do and Up correspond to reservoirs, downstream, and upstream sites, respectively.

profiles were aligned using internal control samples, amplification products of some samples being loaded onto each gel and used as migration markers. The molecular richness was calculated as the total number of bands/phylotypes for each DGGE profile.

\subsection{Fungal contribution to decomposition}

Changes in fungal assemblages can affect litter breakdown, either directly or indirectly, by modifying the activity of shredder species (Arsuffi and Suberkropp, 1989; Suberkropp, 1992; Graça et al., 2001; Bundschuh et al., 2011). Direct consequences of microbial community responses to disturbances on ecosystem functioning were evaluated by measuring the production of fine particulate organic matter (FPOM) by fungi alone at $24 \mathrm{~h}$ and at $72 \mathrm{~h}$. The experiments were carried out in plastic containers $(125 \mathrm{~mL})$, filled with $60 \mathrm{~mL}$ filtered stream water (Whatman ${ }^{\circledR}, 0.45 \mu \mathrm{m}$ pore size). Four microcosms were carried out for each site and each exposure time. Each microcosm received two leaf discs $(\varnothing 16 \mathrm{~mm})$ from the corresponding site. The microcosms were placed for $24 \mathrm{~h}$ or $72 \mathrm{~h}$ in a thermostated chamber $\left(8 \pm 1^{\circ} \mathrm{C}\right.$, i.e. a value close to the average temperature prevailing at the study site). At the end of incubation, water from the microcosms was filtered on a $0.45 \mu \mathrm{m}$ pore size, $25 \mathrm{~mm}$ diameter, nitrate cellulose membrane (Whatman ${ }^{\circledR}$ ). The membrane was first washed with pure water, dried at $80^{\circ} \mathrm{C}$ for $48 \mathrm{~h}$ and then weighed to the nearest $0.001 \mathrm{mg}$. After filtration, the membrane was dried at $80^{\circ} \mathrm{C}$ for $12 \mathrm{~h}$ and then weighed to determine the mass of FPOM produced.

\subsection{Feeding trials of stream-conditioned leaves by two detritivore species}

The bottom-up effects of fungal responses were evaluated by using short-term nonchoice feeding assays (Elger and Lemoine, 2005) for each field conditioning time. We used two species with different feeding habits that were abundant in the study sites: the amphipod G. pulex (L.) and the limnephilid Allogamus auricollis (Pictet). At each leaf bag sampling time, individuals of both species were collected at the reference site (i.e., Up1) and acclimatised to laboratory conditions for $24 \mathrm{~h}\left(8 \pm 1^{\circ} \mathrm{C}\right.$, filtered water from reference site, without food). The experiments were carried out in a microcosm similar to that used for fungal contribution trials. For each sampling date, site and species, litter consumption measurements were carried in ten microcosm replicates. For each site, ten conditioned leaves were haphazardly chosen and two pairs of 16$\mathrm{mm}$ leaf discs were cut from the same leaf, that is, one pair for each species. For each microcosm, one disc was exposed to the macroinvertebrates and the control disc was enclosed in a small bag $(2.5 \mathrm{~cm} \times 2.5 \mathrm{~cm}, 500 \mu \mathrm{m}$ mesh size $)$ rendering it unavailable for consumption. Finally, a single G. pulex or A. auricollis was placed into each microcosm, which was then placed in a thermostated chamber $\left(8 \pm 1^{\circ} \mathrm{C}\right)$. The length of the feeding trial was adjusted to 
Table 1

Main physicochemical parameters characterising water chemistry and sediment contamination gradients in metal and PAHs for reservoir and river sites.

\begin{tabular}{|c|c|c|c|c|c|c|c|c|c|}
\hline & \multicolumn{4}{|c|}{ Reservoir sites $(n=4)$} & \multicolumn{5}{|c|}{ River sites $(n=5)$} \\
\hline & Re1 & Re2 & Re3 & Re4 & Up1 & Do1 & Do2 & Do3 & Do4 \\
\hline \multicolumn{10}{|l|}{ Water chemistry } \\
\hline $\mathrm{pH}$ & 8.10 & 8.50 & 8.10 & 8.20 & 8.10 & 8.20 & 8.15 & 8.35 & 8.20 \\
\hline Temperature $\left({ }^{\circ} \mathrm{C}\right)$ & 9.50 & 10.50 & 10.10 & 9.10 & 8.70 & 8.80 & 9.90 & 9.00 & 9.20 \\
\hline Nitrate $\left(\mathrm{mg} \mathrm{L}^{-1}\right)$ & 4.10 & 3.00 & 2.20 & 2.30 & 4.20 & 4.30 & 3.20 & 2.20 & 2.20 \\
\hline Nitrite $\left(\mathrm{mg} \mathrm{L}^{-1}\right)$ & $<0.02$ & $<0.02$ & $<0.02$ & $<0.02$ & $<0.02$ & $<0.02$ & $<0.02$ & $<0.02$ & $<0.02$ \\
\hline Ammonia $\left(\mathrm{mg} \mathrm{L}^{-1}\right)$ & $<0.05$ & $<0.05$ & $<0.05$ & $<0.05$ & $<0.05$ & $<0.05$ & $<0.05$ & $<0.05$ & $<0.05$ \\
\hline Dissolved oxygen $\left(\mathrm{mg} \mathrm{L}^{-1}\right)$ & 12.40 & 12.50 & 11.90 & 11.40 & 11.30 & 11.30 & 11.00 & 9.80 & 10.50 \\
\hline Conductivity $\left(\mu \mathrm{S} \mathrm{cm}^{-1}\right)$ & 416.0 & 329.0 & 305.0 & 364.0 & 412.0 & 411.0 & 347.0 & 361.0 & 325.0 \\
\hline Dissolved organic carbon $\left(\mathrm{mg} \mathrm{L}^{-1}\right)$ & 1.40 & 1.70 & 1.80 & 1.80 & 1.50 & 1.40 & 1.70 & 1.70 & 1.80 \\
\hline Phosphorus $\left(\mathrm{mg} \mathrm{L}^{-1}\right)$ & 0.006 & 0.01 & 0.01 & $<0.005$ & $<0.005$ & 0.01 & 0.02 & 0.01 & 0.02 \\
\hline \multicolumn{10}{|l|}{ Metal contamination in sediments ( $\mathrm{mg} \mathrm{kgDW}^{-1}$ ) } \\
\hline Aluminium (Al) & $3.7 \times 10^{3}$ & $2.5 \times 10^{3}$ & $2.1 \times 10^{3}$ & $4.4 \times 10^{3}$ & $0.8 \times 10^{3}$ & $1.2 \times 10^{3}$ & $1.0 \times 10^{3}$ & $0.7 \times 10^{3}$ & $0.7 \times 10^{3}$ \\
\hline Cadmium (Cd) & $<0.20$ & $<0.20$ & 0.20 & 0.30 & $<0.20$ & $<0.20$ & $<0.20$ & $<0.20$ & 0.30 \\
\hline Lead $(\mathrm{Pb})$ & 9.10 & 11.50 & 32.00 & 23.90 & 4.90 & 4.70 & 16.10 & 18.80 & 82.90 \\
\hline Chromium (Cr) & 21.30 & 14.90 & 12.80 & 32.80 & 9.20 & 12.90 & 6.30 & 4.90 & 5.00 \\
\hline Copper $(\mathrm{Cu})$ & 4.10 & 24.00 & 45.30 & 32.20 & 2.10 & 1.70 & 5.50 & 2.90 & 21.60 \\
\hline Nickel (Ni) & 9.40 & 10.80 & 6.50 & 16.90 & 5.10 & 5.90 & 4.90 & 4.30 & 3.10 \\
\hline Mercury (Hg) & $<0.02$ & $<0.02$ & 0.02 & 0.04 & $<0.02$ & $<0.02$ & $<0.02$ & $<0.02$ & $<0.02$ \\
\hline $\operatorname{Zinc}(\mathrm{Zn})$ & 26.90 & 52.40 & 78.20 & 85.70 & 17.50 & 13.90 & 22.30 & 55.50 & 30.60 \\
\hline \multicolumn{10}{|l|}{ PAH contamination in sediments $\left(\mu \mathrm{ggDW}^{-1}\right)$} \\
\hline Benzo(a)pyrene (BaP) & 23.00 & 62.00 & 535.00 & 286.00 & $<10$ & 197.00 & 46.00 & 67.00 & 44.00 \\
\hline Benzo(a)anthracene (BaA) & 20.00 & 46.00 & 649.00 & 233.00 & $<10$ & $<10$ & 44.00 & 68.00 & 55.00 \\
\hline Benzo(k)fluoranthene (BkF) & 12.00 & 28.00 & 206.00 & 121.00 & $<10$ & 90.00 & 22.00 & 36.00 & 31.00 \\
\hline Benzo(ghi)perylene (BgP) & 5.00 & 47.00 & 43.00 & 133.00 & $<10$ & 46.00 & 28.00 & 153.00 & 36.00 \\
\hline Fluoranthene (Fluo) & 46.00 & 127.00 & 1919.00 & 545.00 & $<40$ & 443.00 & 105.00 & 161.00 & 130.00 \\
\hline Indeno(1,2,3-cd)pyrene (Ind) & 21.00 & 29.00 & 395.00 & 118.00 & $<10$ & 108.00 & 18.00 & 36.00 & 33.00 \\
\hline Phenanthrene (Phen) & $<50$ & $<50$ & $<50$ & 180.00 & $<50$ & $<50$ & $<50$ & 119.00 & 63.00 \\
\hline Coordinates on F1 of PCA performed on metals & 0.250 & -1.004 & -1.635 & -5.261 & 1.944 & 1.618 & 2.070 & 1.881 & 0.509 \\
\hline Coordinates on F1 of PCA performed on PAHs & 2.246 & 1.773 & -5.028 & -1.510 & 2.426 & 1.973 & 1.634 & -0.309 & 1.717 \\
\hline
\end{tabular}

reach $50 \%$ of mass loss in at least one treatment, that is, $24 \mathrm{~h}$ for G. pulex and $72 \mathrm{~h}$ for A. auricollis.

A total of 540 microcosms were used (nine sites $\times$ two species $\times$ three times $\times$ ten replicates). At the end of each feeding trial, the animal, the control disc and the remaining exposed disc were removed, oven-dried $\left(105^{\circ} \mathrm{C}, 24 \mathrm{~h}\right)$, weighed to the nearest $0.001 \mathrm{mg}$, ashed $\left(550^{\circ} \mathrm{C}, 4 \mathrm{~h}\right)$ and reweighed. Consumed leaf mass was calculated as the difference of AFDM remaining in the control versus exposed disc. Consumption rate (CR) was calculated as the consumed leaf mass per day per gram of macroinvertebrate body dry mass (Findlay and Arsuffi, 1989). FPOM release was determined in four out of the ten replicates for each treatment by following the same procedure described above and was determined for each invertebrate species by subtracting the FPOM produced by fungi at $24 \mathrm{~h}$ for G. pulex and at $72 \mathrm{~h}$ for A. auricollis. Four $\mathrm{mg}( \pm 0.31 \mathrm{mg})$ of exposed leaf litter and $3 \mathrm{mg}( \pm 0.29 \mathrm{mg})$ of macroinvertebrate individuals collected at the end of the feeding trials were analysed, in triplicates for each site $\times$ time treatment, using a CHN elementary analyser (Carlo Erba NA 2100) to quantify the organic matter content in terms of $C$ and nitrogen $(\mathrm{N})$. Similarly, the phosphorus (P) content was determined in leaf litter and macroinvertebrates after persulfate digestion. C:N:P ratios were expressed as molar ratios.

\subsection{Statistical analyses}

Principal component analyses (PCAs) were carried out to investigate the site distribution according to metal and $\mathrm{PAH}$ concentrations in $\mathrm{mol} \mathrm{g}^{-1}$ sediment. Several between-sites comparisons were performed to discriminate the biological responses of fungal communities to multiple stressors context: (a) noncontaminated sites (Up1/Re1/Do1) to identify responses to physical disturbances associated with dam presence; (b) reservoir sites (Re1/Re2/Re3/Re4) to describe responses to chemical disturbances associated with contaminated sediment and (c) downstream sites (Do1/Do2/Do3/Do4) to characterise responses to cumulated impacts associated with both dam presence and contaminated sediment stored in the associated reservoirs. These comparisons were performed using analyses of covariance (ANCOVA) followed by one-way ANOVA and multiple-comparison tests (Tukey's HSD). Given that conditioning of leaves by aquatic hyphomycetes induced changes in litter elementary quality, we compared the elemental ratios of leaves and invertebrates as well as the stoichiometric balance between consumers and their food. Multiple linear regressions were used to explore the relations between fungi (i.e. fungal biomass and molecular richness) and litter elemental ratios (i.e. C/P and $\mathrm{C} / \mathrm{N}$ ). One-way ANOVA analyses were performed to compare $\mathrm{CR}$ of each invertebrate species between sites according to the multiple stressors context. Within-trial comparisons were then performed using Tukey's HSD test. Generalised linear models (GLMs) with stepwise selection (AIC criterion) and hierarchical partitioning (HP) method were used to assess (a) effects of physical and chemical disturbances using synthetic variables on fungal communities associated with decaying leaves and (b) functional consequences of fungal responses (i.e. FPOM production by fungi and shredders, leaf breakdown by shredders). The coordinates of each site to the first axis of PCAs performed for metals and for PAHs were used as synthetic variables of contamination levels in metals and PAHs, respectively. Synthetic variables of physical impacts were defined by a factor at two levels, that is, 'reservoir' or 'downstream of dam'. HP reduces collinearity problems by determining the independent contribution of each explanatory variable to the response variable and separates it from the joint contribution, resulting from correlation with other variables. This enables one to rank the importance of the covariates in explaining the response variable independently of the other covariates. The amount of deviance accounted for $\left(D^{2}\right)$ of each model was calculated according to the formula proposed by Guisan and Zimmermann (2000) (Eq. (1)):

$D^{2}=\frac{\text { model } \$ \text { null } \cdot \text { deviance }- \text { model } \$ \text { deviance }}{\text { model } \$ \text { null } \cdot \text { deviance }}$ 
The $D$-squared of GLMs is the equivalent of the $R$-squared value of linear models that measures the proportion of variation that the model accounts for. For all parametric analyses, normal distribution and homoscedasticity were respected. $\mathrm{R}$ software ( $\mathrm{R}$ Development Core Team, 2008), ade4 library (Chessel et al., 2004) and hier.part (Walsh and MacNally, 2004) were used for all statistical analyses.

\section{Results}

\subsection{Sediment contamination of study sites}

The PCA performed on metal concentrations in sediments (Fig. 2A) discriminated four groups of site. The first PCA axis (59\%) separated the stream sites and the non-contaminated reservoir (Re1) from the other reservoirs because of higher metal concentrations. According to the first axis, the four reservoirs represented a gradient of sediment contamination in metals from the leastcontaminated reservoir (Re1) to the most-contaminated reservoir (Re4). The second axis (17\%) discriminated sites downstream of contaminated reservoirs (i.e. Do2, Do3 and Do4) from stream sites associated with Re1 because of higher metal concentrations, specifically lead. The PCA performed on PAH concentrations in sediments (Fig. 2B) discriminated three groups of site. The first axis (66\%) separated $\operatorname{Re} 4, \operatorname{Re} 3$ and its associated downstream site (Do3) from the other sites because of higher PAH concentrations. More specifically, Re3 exhibited higher concentrations of benzo(a)anthracene $(\mathrm{BaA})$, benzo(a)pyrene $(\mathrm{BaP})$, fluoranthene (Fluo) and indeno(1,2,3-cd)pyrene (Ind). Re4 exhibited higher concentrations of benzo(k)fluoranthene $(\mathrm{BkF})$ and Do3 higher concentrations of phenanthrene (Phen) and benzo(ghi)perylene (BgP).

\subsection{Responses of fungal communities}

In the absence of sediment contamination (Fig. $3 \mathrm{~A}$ and Table 2), fungal biomass differed significantly among sites ( $F=20.6$, $P<0.001)$ and exposure time $(F=42.5, P<0.001)$, with a higher biomass in the upstream site (Up1) than in the reservoir (Re1, $P<0.001)$ and in the downstream site (Do1) at $14(P<0.001)$ and 28 days $(P<0.001)$. Molecular richness was significantly different among sites $(F=44.7, P<0.001)$ and exposure time $(F=35.6$, $P<0.001)$, with a higher richness in the reservoir than in the stream sites at 14 and 28 days $(P<0.001$, Fig. 3B). For reservoir sites (Fig. $3 \mathrm{C}$ and Table 2 ), fungal biomass differed significantly among sites $(F=8.1, P<0.01)$ and exposure time $(F=11.6, P<0.001)$ with a lower biomass in contaminated reservoirs (Re2, Re3 and Re4) than in the non-contaminated one (Re1) at 45 days, and a maximal richness reached at 28 days for contaminated sites compared with Re1. Molecular richness (Fig. 3D and Table 2) also differed significantly between sites $(F=28.1, P<0.001)$ and exposure time $(F=26.5, P<0.001)$. Fungal richness was significantly lower in the most contaminated site (Re4) than in non-contaminated reservoir at 14 and 28 days $(P<0.001)$. Fungal biomass was significantly different between downstream sites $(F=27.1, P<0.001$, Fig. 3E and Table 2$)$ and exposure time $(F=4.5, P<0.05)$ with a lower biomass downstream of contaminated reservoirs (Do2, Do3 and Do4) than in the site downstream of the non-contaminated reservoir (Do1), particularly at 45 days $(P<0.001)$. The maximal production downstream of contaminated reservoirs was reached at 28 days earlier than downstream from Re1. Molecular richness (Fig. 3F and Table 2) also differed significantly among sites $(F=18.9, P<0.001)$ and exposure time $(F=21.6, P<0.001)$. Although no clear pattern related to cumulated stressors was observed, species richness in Do2 site was significantly higher than in other downstream sites, particularly at 28 and 45 days $(P<0.001)$.
GLMs summarised the effects of stressors on fungal communities (Table 3). No significant effect of PAH contamination was identified by the models. For fungal biomass, the selected model explained $85.5 \%$ of the biological response. The best predictors were the presence of a dam and metal contamination, which independently contributed to $47.9 \%$ and $46.5 \%$ of fungal biomass variation, respectively. For molecular richness, the selected model explained $56.1 \%$ of the variance, which was independently explained by the presence of a dam and metal contamination at $67.4 \%$ and $28.1 \%$, respectively.

\subsection{Effects on higher trophic levels and leaf breakdown}

Consumption rates, FPOM production and elemental ratios of leaves were determined to assess the consequences of litter conditioning changes on higher trophic levels and leaf breakdown. Significant correlations between fungal biomass and the elemental ratios of leaves were identified for the $\mathrm{C} / \mathrm{P}(r=-0.4, P<0.001)$ and $\mathrm{C} / \mathrm{N}(r=-0.5, P<0.001)$ ratios, indicating $\mathrm{P}$ and $\mathrm{N}$ enrichment with increasing biomass. Similarly, a significant linear relation was identified between molecular richness and the $\mathrm{C} / \mathrm{N}$ ratios of leaves $(r=-0.43, P<0.001)$, indicating $\mathrm{N}$ enrichment with increasing richness. Molecular richness and $\mathrm{C} / \mathrm{P}$ ratios of leaves were the best predictors of FPOM produced by aquatic hyphomycetes. These explained $68.7 \%$ of the total deviance (Table 4 ). C/P ratios of leaves explained independently $46.7 \%$ of FPOM production, with the latter being lower for higher C/P ratios (Fig. 4A). Consequently, FPOM production by aquatic hyphomycetes increased with leaf $\mathrm{P}$. A similar proportion of FPOM production (43.3\%) was explained by molecular richness, with higher production occurring with increased richness (Fig. 4B).

CRs of G. pulex were significantly lower for leaves from Re1 than for leaves from the upstream site (Up1), for the second ( $F$ value $=17.6, P<0.001)$ and third $(F$-value $=4.9, P<0.05)$ feeding trials (Fig. 5A). CRs of G. pulex were also lower for leaves from the downstream site (Do1) compared with leaves from the upstream site, but only for the first feeding trial $(F$-value $=6.0, P<0.01)$. For comparisons of $\mathrm{CR}$ associated with reservoirs (Fig. 5B), the CR of G. pulex was significantly lower for leaves from the more contaminated reservoir $(\operatorname{Re} 4)$ for the first feeding trial $(F$-value $=3.7$, $P<0.05$ ). For the second trial, $C R$ was higher for leaves from the non-contaminated reservoir (Re1) than for leaves from contaminated reservoirs $(F$-value $=6.1, P<0.01)$. $C R$ was no different for the third trial. For leaves exposed in downstream sites (Fig. 5C), CR rates from Do1 were lower than other downstream sites for the first feeding trials, but significantly higher than for leaves from sites downstream of the two most-contaminated reservoirs for the second trial $(F$-value $=9.0, P<0.001)$ and the most contaminated reservoir for the third trial $(F$-value $=4.4, P<0.05)$.

CRs of $A$. auricollis were significantly higher for leaves from Re1 than for leaves from the upstream site (Up1) and downstream dam (Do1), particularly for the first $(F$-value $=170, P<0.001)$ and second $(F$-value $=9.3, P<0.001)$ feeding trials (Fig. 5D). CRs were also lower for leaves from the downstream site (Do1) compared with leaves from the upstream site for the second feeding trial $(F$-value $=9.3, P<0.01)$. For comparisons of $C R$ associated with reservoirs (Fig. 5E), CRs of A. auricollis were significantly lower for leaves from the contaminated reservoirs compared with leaves from the non-contaminated reservoir for the first $(F$-value $=55.1$, $P<0.001)$ and second feeding trial $(F$-value $=39.2, P<0.001)$. For the third trial, CRs were lower for leaves from the most-contaminated reservoir $(\operatorname{Re} 4)$ compared with the other reservoirs $(F$-value $=3.9$, $P<0.05$ ). For CRs of A. auricollis for leaves exposed in downstream sites (Fig. 5F), no clear pattern was identified.

The best predictors of the $\mathrm{CR}$ rate of $G$. pulex were fungal biomass, molecular richness, $\mathrm{N} / \mathrm{P}$ and $\mathrm{C} / \mathrm{N}$ ratios of the leaves. These 

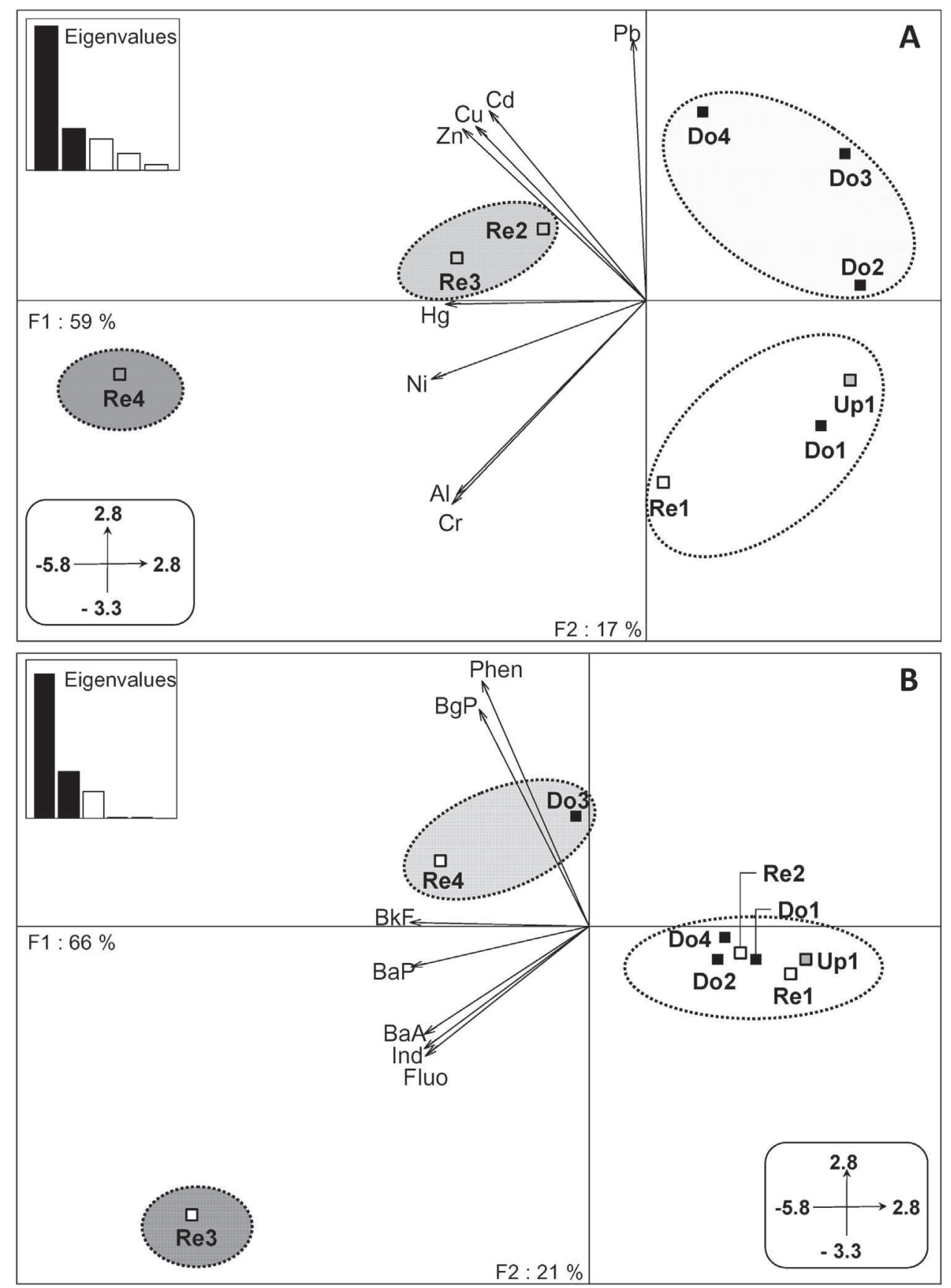

Fig. 2. Principal component analysis performed on concentrations expressed in mol g ${ }^{-1}$ of metallic (A) and PAH (B) pollutants in the sediments of reservoir and river sites.

Table 2

Results of ANCOVA analyses performed for fungal biomass and richness. ${ }^{\mathrm{a}}$

\begin{tabular}{|c|c|c|c|c|c|c|c|c|}
\hline & \multicolumn{4}{|c|}{ Fungal biomass } & \multicolumn{4}{|c|}{ Fungal richness } \\
\hline & \multicolumn{2}{|c|}{ Time effect } & \multicolumn{2}{|c|}{ Site effect } & \multicolumn{2}{|c|}{ Time effect } & \multicolumn{2}{|c|}{ Site effect } \\
\hline & $F$-value & $P$-value & $F$-value & $P$-value & $F$-value & $P$-value & $F$-value & $P$-value \\
\hline $\begin{array}{l}\text { Physical stressor } \\
\text { Up1/Re1/Do1 }\end{array}$ & 42.5 & $<0.001$ & 20.6 & $<0.001$ & 35.6 & $<0.001$ & 44.7 & $<0.001$ \\
\hline $\begin{array}{l}\text { Chemical stressor } \\
\text { Re1/Re2/Re3/Re4 }\end{array}$ & 11.6 & $<0.001$ & 8.1 & $<0.01$ & 26.5 & $<0.001$ & 28.1 & $<0.001$ \\
\hline $\begin{array}{l}\text { Cumulative stressor } \\
\text { Do1/Do2/Do3/Do4 }\end{array}$ & 4.5 & $<0.05$ & 27.1 & $<0.001$ & 21.6 & $<0.001$ & 18.9 & $<0.001$ \\
\hline
\end{tabular}

a Time effect and station effect are reported for each comparison according physical, chemical or cumulative stressors. 

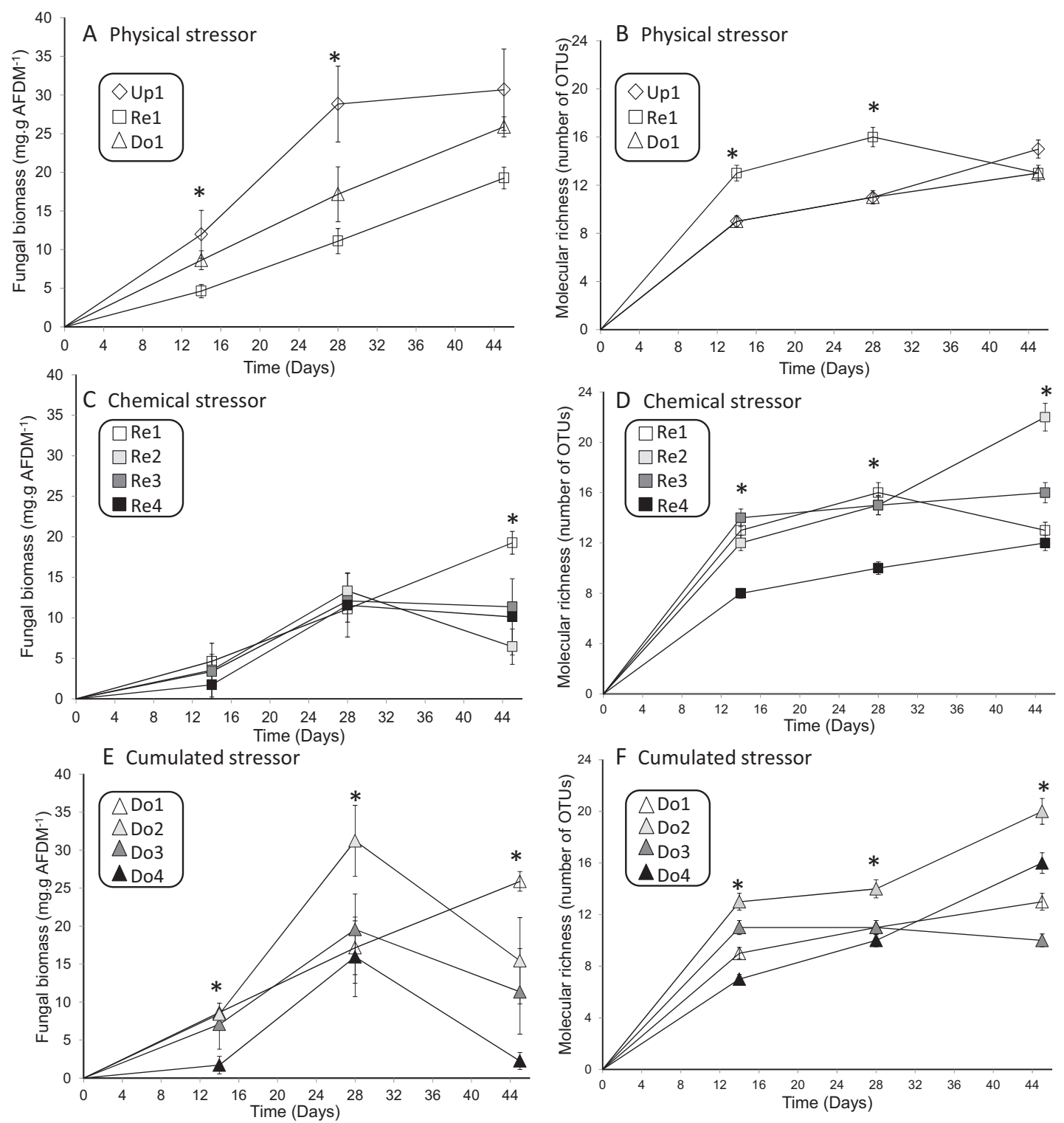

Fig. 3. Between-site comparisons to identify effects of physical (A, B), chemical (C, D) and cumulated impacts (E, F) on fungal biomass ( \pm SD) and molecular richness ( \pm SD) measured on stream-conditioned leaves. Significant differences between sites identified by the ANOVA analysis performed at each exposure time are indicated by an asterisk.

explained $76.6 \%$ of the total deviance. Among these variables, only fungal biomass and molecular richness were significant. Fungal biomass was the best explicative variable, explaining independently $43.8 \%$ of the variation. CR increased when fungal biomass was high (Fig. 6A). Molecular richness explained 22.2\% of the variation and showed a positive relation with CR (Fig. 6B). Fungal biomass and C/P stoichiometric balances between leaves and detritivores were the best predictors of FPOM production by G. pulex.
These explained $35.7 \%$ of the total deviance. Among these variables, fungal biomass was the best predictor. It explained independently $46.4 \%$ of the total variance with a higher FPOM production occurring when fungal biomass increased, notably during the early stages of fungal colonisation (Fig. 6C). Stoichiometric balances in P between leaves and consumers explained $19.7 \%$ of the total variance. FPOM production was higher when the stoichiometric balance in $\mathrm{P}$ between leaves and detritivores increased. Fungal biomass,

Table 3

Results derived from the hierarchical partitioning and generalised linear models performed on fungal responses to multiple stressors. ${ }^{a}$

\begin{tabular}{|c|c|c|c|c|c|}
\hline Dependent variable & $D^{2}(\%)$ & Independent variable & Coefficients & $P$-value & Contribution (\%) \\
\hline \multirow[t]{3}{*}{ Fungal biomass } & \multirow[t]{3}{*}{85.5} & Metals & -0.26 & $<0.001$ & 46.5 \\
\hline & & PAHs & -0.07 & NS & NS \\
\hline & & Dam & -14.33 & $<0.001$ & 47.9 \\
\hline \multirow[t]{3}{*}{ Molecular richness } & \multirow[t]{3}{*}{56.1} & Metals & -0.09 & $<0.001$ & 28.1 \\
\hline & & PAHs & & Not selected & \\
\hline & & Dam & -0.50 & $<0.001$ & 67.4 \\
\hline
\end{tabular}

a Variables shown for each multiple regression were conserved using a stepwise procedure of variable selection. The relative independent contribution of each environmental predictor is given as a percentage of the total independent contribution. 
Table 4

Results derived from the hierarchical partitioning and generalised linear models performed on relationships between fungal indicators and higher trophic levels. (L) and ( $G$ ) correspond to Leaves and G. pulex, respectively. ${ }^{\text {a }}$

\begin{tabular}{|c|c|c|c|c|c|}
\hline Dependent variable & $D^{2}(\%)$ & Independent variable & Coefficients & $P$-value & Contribution (\%) \\
\hline \multirow[t]{2}{*}{ FPOM production by fungi } & \multirow[t]{2}{*}{68.7} & Fungal richness & 0.300 & $<0.01$ & 43.3 \\
\hline & & $\mathrm{C}: \mathrm{P}$ ratio $(\mathrm{L})$ & -0.014 & $<0.01$ & 46.7 \\
\hline \multirow[t]{4}{*}{ Palatability for G. pulex } & \multirow[t]{4}{*}{76.6} & Fungal biomass & 0.016 & $<0.001$ & 43.8 \\
\hline & & Fungal richness & 0.032 & $<0.01$ & 22.2 \\
\hline & & $\mathrm{N}: \mathrm{P}$ ratio $(\mathrm{L})$ & -0.015 & NS & NS \\
\hline & & C:N ratio $(\mathrm{L})$ & -0.062 & NS & NS \\
\hline \multirow[t]{5}{*}{ FPOM production by G. pulex } & \multirow[t]{5}{*}{35.7} & Fungal biomass & 0.425 & $<0.001$ & 46.4 \\
\hline & & $\mathrm{C}:$ P ratio $(\mathrm{L})$ & -0.012 & $<0.01$ & NS \\
\hline & & C:N ratio $(\mathrm{L})$ & 0.378 & $<0.01$ & NS \\
\hline & & $\mathrm{N}: P$ ratio $(\mathrm{L})$ & 0.144 & NS & NS \\
\hline & & $\mathrm{C}: \mathrm{P}(\mathrm{L}) / \mathrm{C}: \mathrm{P}(\mathrm{G})$ & 0.615 & $<0.001$ & 19.7 \\
\hline \multirow[t]{5}{*}{ Palatability for A. auricollis } & \multirow[t]{5}{*}{72.1} & Fungal biomass & 0.018 & $<0.001$ & 40.3 \\
\hline & & Fungal richness & 0.037 & $<0.01$ & 27.7 \\
\hline & & $\mathrm{C}:$ P ratio $(\mathrm{L})$ & 0.004 & NS & NS \\
\hline & & $\mathrm{C}: \mathrm{N}$ ratio (L) & -0.099 & NS & NS \\
\hline & & $\mathrm{N}: \mathrm{P}$ ratio $(\mathrm{L})$ & -0.062 & NS & NS \\
\hline
\end{tabular}

a Variables shown for each multiple regression were conserved using a stepwise procedure of variable selection. The relative independent contribution of each environmental predictor is given as a percentage of the total independent contribution.
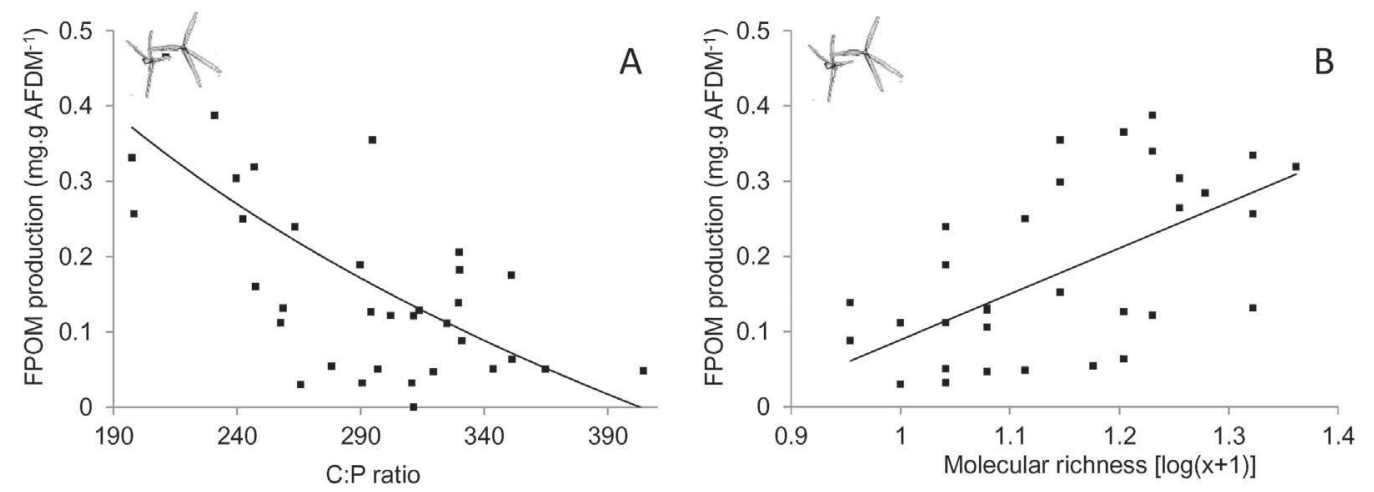

Fig. 4. Relationships between FPOM produced by fungi coming from laboratory experiments and C:P ratios of leaves (A) or molecular richness (B), according to the best predictors selected by the hierarchical partitioning and generalised linear models.

molecular richness and elemental ratios of leaves explained $72.1 \%$ of the total deviance in $\mathrm{CR}$ by A. auricollis. Fungal biomass and molecular richness were the best predictors, explaining $40.3 \%$ and $27.7 \%$ of the total variance, respectively. CR was higher when fungal biomass (Fig. 6D) and molecular richness (Fig. 6E) increased. No significant model was selected for FPOM production by A. auricollis.

\section{Discussion}

\subsection{Fungal indicators: response to multiple stressors}

Regardless of the contaminated sediment stored within reservoirs, the presence of a dam significantly reduced fungal production in reservoirs and downstream reaches. To our knowledge, only four studies have examined the impacts of dams on downstream fungal communities (Muehlbauer et al., 2009; Mendoza-Lera et al., 2012; Menéndez et al., 2012; González et al., 2013) and none on reservoir communities. Among these, only one study evaluated the fungal biomass downstream of dams (Muehlbauer et al., 2009). The authors also reported a decrease in fungal biomass relative to the upstream sites, probably because of flow reduction and cooler water below the dam. Some studies performed under laboratory conditions have examined the impacts of flow changes on fungal communities associated with decaying leaves (Ferreira and Graça, 2006; Schlief and Mutz, 2009) and reported lower sporulation rates, cumulative conidial production, fungal biomass and diversity with a reduction in water flow. Similar to the study of Mendoza-Lera et al. (2012) on five headwater dams, no significant change in fungal richness was observed below dams. By contrast, higher species richness was found in the non-contaminated reservoir compared with upstream waters. Water velocity is essential for the dispersal of aquatic hyphomycetes by means of conidia or mycelia associated with detrital organic matter (e.g. leaves, wood or roots). Thus, it is likely that the presence of dams reduces this passive dispersal, leading to their accumulation and sedimentation in reservoirs. It is likely that they survive in these locations not as conidia but as mycelia or resistant, dormant structures associated with plant detritus (Bärlocher, 2009).

In aquatic ecosystems, the simultaneous occurrence of hydromorphological and chemical disturbances is common, especially in the presence of dams. Despite this, risk assessments associated with contaminants stored in sediments is currently based on laboratory toxicity tests of laboratory-culturable species and under one set of fixed conditions. Consequently, extrapolation from these tests to natural populations and communities is a crucial challenge, and is subject to large uncertainties (Forbes et al., 2001; Calow and Forbes, 2003; Rubach et al., 2011). To solve these uncertainties, several methodologies have been proposed, such as the study of field species assemblages or integrative approaches that combine chemical, ecotoxicological and ecological surveys (e.g. Clements et al., 2002; Beasley and Kneale, 2004; Borgmann et al., 2001; Sorensen et al., 2007). Even though some studies have focused more specifically on functional-based approaches at the community level by using biotrait profiles or niche shifts (Colas et al., 2013a, 

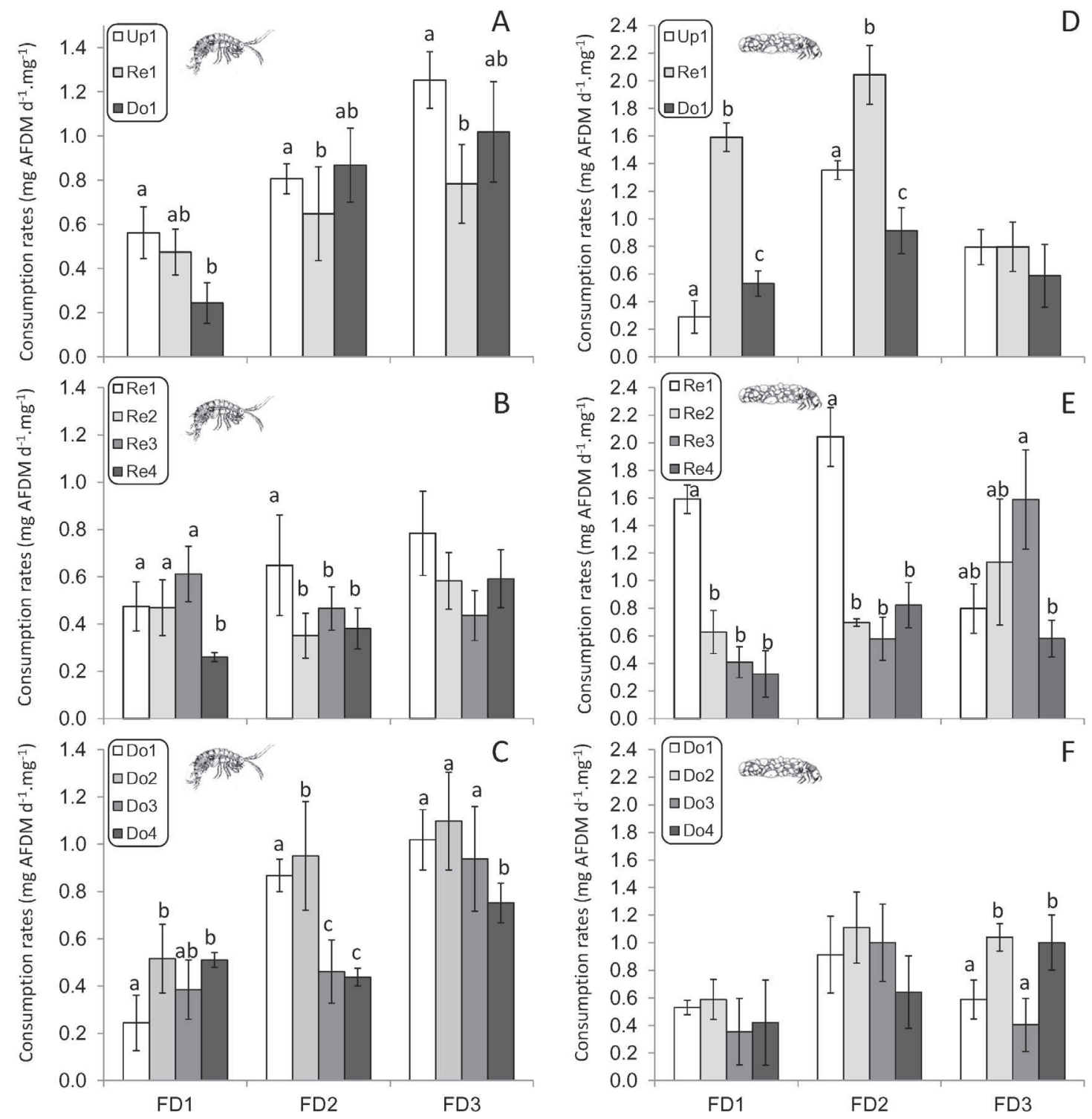

Fig. 5. Consumption rates $( \pm \mathrm{SD})$ of G. pulex $(\mathrm{A}-\mathrm{C})$ and A auricollis (D-F) from three laboratory feeding trials performed on leaves from each study site and for different leaf incubation times [i.e. 14 (FD1), 28 (FD2) or 45 (FD3) days]. Comparisons were performed in each feeding trial to identify differences between consumption rates of leaves coming from sites subjected to physical (A, D), chemical (B, E) or cumulated stressors (C, F).

2014), more studies are needed to identify and predict the consequences of stressors, on ecosystem functioning, particularly when chemical and physical stressors co-occur. Although few studies have reported an influence of clogging and sediment structure on leaf breakdown and associated fungal communities (e.g. Danger et al., 2012; Navel et al., 2012), the effects of sediment contamination on fungi are poorly documented. Nonetheless, some studies on the effects of metal contamination in water performed under laboratory and field conditions generally reported a decrease in the growth, sporulation and diversity of aquatic hyphomycetes (Miersch et al., 2001; Medeiros et al., 2010), as well as associated performance metrics, such as fungal biomass and leaf-processing rates [see the meta-analysis of Lecerf and Chauvet (2008)] with increased concentrations of pollutants. In the current study, we observed a significant decrease in fungal biomass with the increasing contamination of sediments by metals. For molecular richness, we found a significant impact of sediment contamination exclusively for the highest level of contamination (i.e. Re4). In contrast, we observed a significant impact on fungal biomass as soon the first level of contamination, suggesting that fungal biomass may be a more sensitive indicator of sediment contamination than molecular richness. The effect of chemical stressors is rarely studied, despite the concomitant presence of physical disturbance. Yet, understanding the impacts of dams on downstream reaches requires consideration of the cumulative impact of flow changes and the contamination stored in reservoirs. Indeed, we observed a significant decrease in fungal biomass downstream of dams with increasing metal contamination of sediments in associated reservoirs, suggesting a synergistic impact of both perturbations on fungi associated with decaying leaves. It is likely that this cumulative impact is associated with the depletion of water quality downstream (e.g. a release of pollutants stored within reservoir sediments).

\subsection{Fungal indicators: cascading effects}

Effects of multiple stressors associated with dams on aquatic hyphomycetes could have implications for higher trophic levels by modifying the performances of both fungi and leaf-shredding invertebrates in the processing of coarse particulate organic 

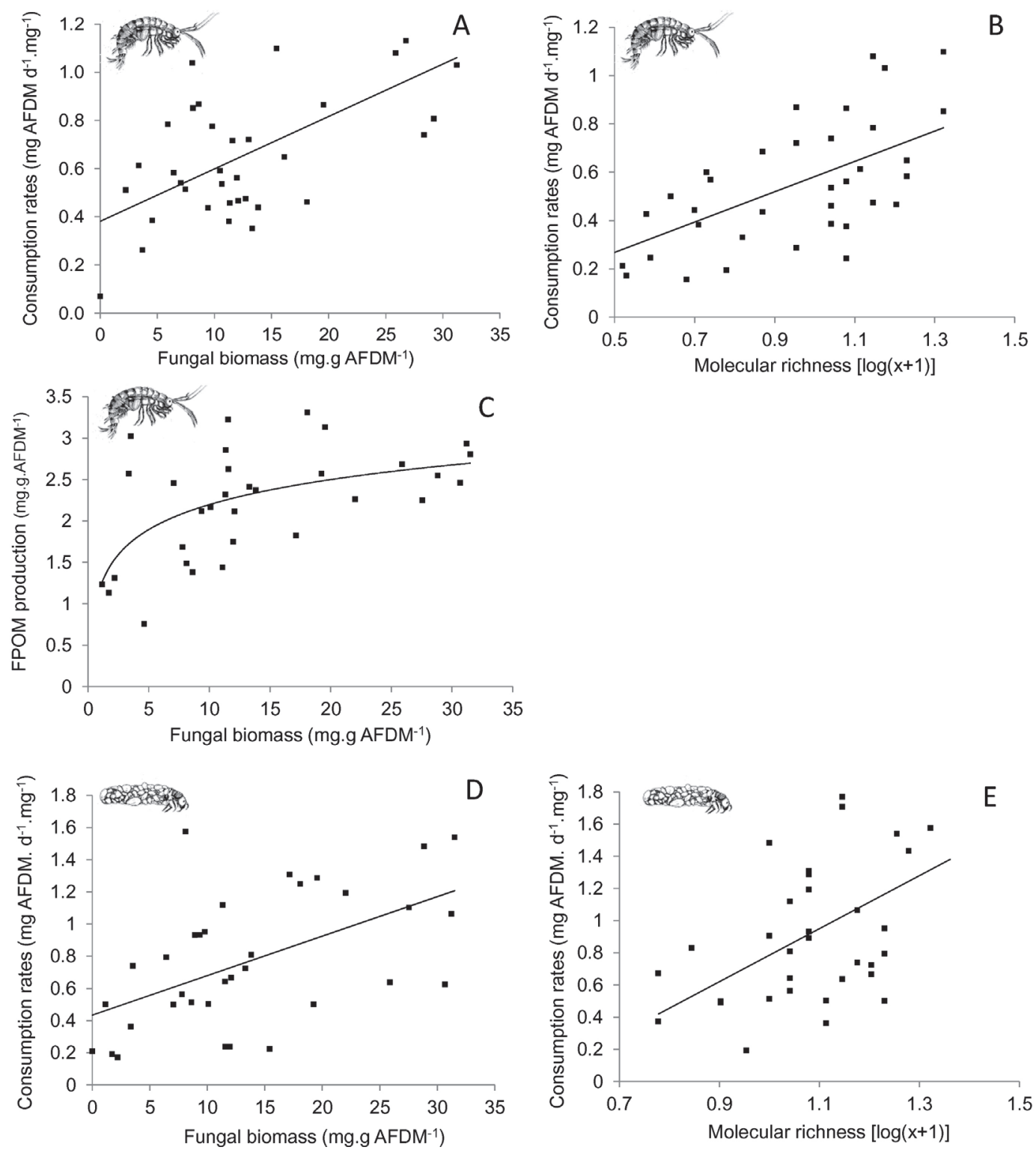

Fig. 6. Relations between consumption rates of G. pulex (A, B) and associated FPOM production (C) or consumption rates of A. auricollis (D, E) from laboratory experiments, and changes in fungal biomass and molecular richness, according to the best predictors selected by the hierarchical partitioning and generalised linear models.

matter. Several experimental studies have provided evidence that the loss of species can affect the efficiency with which resources are processed within an ecosystem (Hector et al., 1999; Tilman et al., 2001; Loreau et al., 2002), although the mechanisms underlying the response are not always well understood (Zak et al., 2003). In this study, decreased fungal richness resulted in a decrease in leaf $P$ content and FPOM production, suggesting a positive linear relationship between fungal richness and ecological function. Nonetheless, extrapolation of this result requires more investigation, for example through complementary in vitro and field experiments. Indeed, whether the species richness of aquatic hyphomycetes interferes with their functional role in leaf breakdown in the context of the present study (i.e. is there a positive link between diversity and function?), is neither simple nor universal and might be nonmonotonic through time and space (e.g. Schwartz et al., 2000). In addition, the positive relationship reported in this study was based on results from laboratory experiments on natural assemblages of fungi and, thus, might not reflect natural communities (e.g. Hodgson et al., 1998). In the present study, negative alterations in fungal communities (i.e. biomass and richness) strongly reduced the shredding activity of $G$. pulex and $A$. auricollis and, ultimately, the production of FPOM, suggesting the potential detrimental effects for higher trophic levels of fungal responses to disturbances. In addition to altering the breakdown of leaf litter mediated by invertebrates, decreased leaf litter quality can have consequences on the ability of invertebrates to cope with disturbances. Indeed, several studies have suggested that fungal conditioning and nutrient content enrichment confer an advantage to Gammarus sp. by positively influencing their survival and/or growth rates (Danger et al., 2013; Graça et al., 2001). In particular, shredder growth is known to depend upon food nutrient content, particularly its P content (Danger et al., 2013). Organisms under stress have to cope with an increased energy demand due to the costs of defence and repair processes (Maltby, 1999). It is clear, from several studies, that exposure to toxicants generally results in a decrease in feeding rates and, hence, energy acquisition (e.g. Maltby, 1999; Zubrod et al., 2010; Funck et al., 2013). As such, feeding rate or absolute consumption is currently used as sublethal endpoint in many studies in ecotoxicology. Consequently, the effects of resource quality reported in the present study might be particularly decisive in the context of 
multiple stressors where shredding macroinvertebrates have increased energy demands to cope with toxic stress. The study of the interactions between the quality of detrital resources and the response of shredders to disturbances is crucial to better understand and predict the fate of detrital organic matter in such systems.

\subsection{Implications for the establishment of fungal-based indicators}

In the context of the current biodiversity crisis, a major challenge in freshwater ecology is to identify indicators sensitive to disturbances whose effects spread to the ecosystem level. Fungal indicators proposed in this study can be considered as sensitive and predictive indicators because of their responses to chemical and physical disturbances and the cascading effects on higher trophic level and ecosystem functioning. In a previous study on the same sites (Colas et al., 2013b), we observed that, in the absence of sediment contamination, leaf breakdown was not disturbed in reservoirs and downstream reaches. Yet, the absence of impaired functioning of ecosystems does not necessarily mean that the disturbances have not disturbed other ecosystem components (e.g. microbial communities), leading to the ecosystem being more vulnerable to additional stressors. By contrast, it means that the effect of dams on communities associated with decaying leaves (e.g. low fungal biomass) might be compensated to maintain leaf breakdown levels. However, the presence of additional stressors, such as contaminated sediments, leads to synergistic impacts on microbial communities and, consequently, on leaf quality and leaf breakdown. The experiments that we performed in the laboratory illustrated that these quality changes led to effects on higher trophic levels. In the field, the consequences of a lowquality resource might be even more significant, the leaf-shredding invertebrates being themselves subjected to the effects of disturbances. Consequently, such indicators at the fungal community level reveal the initial signs of ecosystem functioning alterations and, as such, could be useful biomonitoring tools for environmental agencies. Indeed, ecological assessment based on such indicators could enable managers to implement management policies to prevent the consequences of biodiversity loss on ecosystem functioning and on the goods and services that they provide. Fungal biomass and molecular richness were chosen because analytical methodologies are well known and do not require a high level of expertise. To date, few chemistry laboratories are able to determine fungal biomass and richness according to the analytical methods presented in this study, probably because these indicators have not yet been proposed, or made available, as tools for the biomonitoring. In addition to the indicators used in this study, other fungal indicators could be explored. For instance, microbial enzymatic activities might help predict the effects of disturbance at higher trophic levels, given that invertebrates ingest pre-digested leaves containing enzymes that have prolonged activity in their gut (Bärlocher and Kendrick, 1975). Many efforts are still needed to understand the mechanisms involved in the responses of fungal communities to different stressors and, consequently, in leaf litter processing.

\section{Conclusion}

To date, although reservoirs store a large amount of organic matter, the risk assessments associated with the presence of dams do not integrate the monitoring of the reservoirs (often regarded as a 'black box'), including the effects associated with sediment contamination. Given their increasing numbers, the quality of these systems should have a growing importance in terms of achieving a good ecological status of downstream ecosystems. Indeed, changes in leaf conditioning are likely to delay leaf breakdown, favouring the storage of detrital organic matter in sediments, thereby decreasing $C$ availability for higher trophic levels and downstream reaches. In addition, the accumulation of non-degraded organic matter might modify the biogeochemical functioning of sediments and cause a significant decrease in the water quality of reservoirs and potential cascading effects to downstream ecosystems (e.g. Hupfer and Lewandowski, 2008; Baldwin et al., 2010). Our study shows that consideration of the combined effects of disturbance and organic matter quality is fundamental for predicting dam impacts and understanding the functioning of reservoir ecosystems. Given the importance of the fate of organic matter stored within reservoirs for downstream ecosystems, the microbial compartment associated with decaying leaves could be a powerful indicator of reservoir integrity, which could be especially useful in risk assessments of multiple stressors associated with the presence of dams or for implementing dam removal. This study highlights the sensitivity of the fungal biomass and molecular richness to the multiple stressors associated with run-of-river reservoirs. These indicators would enable one to predict the impairment of ecosystem functioning because of their positive relationships with the performance of fungi and leaf-shredding invertebrates in terms of the break down of leaf detritus. To determine whether fungal biomass and molecular richness could be considered as relevant functional indicators, more studies are needed to explore the responses of fungal-based indicators to different stressors. Many bioassessment tools are based on metrics reflecting community attributes and, even if these tools are widely recognised as useful in a management context, they do not inform on specific changes in ecosystem functioning. Yet, in the current context of global changes that have led to the sixth event of species extinction, bioassessment tools must be focused on functional indicators. Such a framework will require the joint study of the structure and the function of ecosystems with the aim of identifying thresholds beyond which the effects of disturbance on communities lead to impaired ecosystem functioning. The indicators and thresholds coming from this framework should guide public policies and management schemes in managing or preventing the effects of species loss on freshwater ecosystem functioning and services.

\section{Acknowledgements}

This study was supported by the DIESE Program of the National Research Agency - ANR PRECODD. The authors thank Wagner P., Rousselle P., Bigorgne E. and the Natural Park of Haut Jura for their assistance during field and laboratory work. The authors thank the anonymous reviewers for their suggestions and International Science Editing for the spelling corrections that have significantly improved the quality of the manuscript.

\section{References}

Arsuffi, T.L., Suberkropp, K., 1989. Selective feeding by shredders on leaf-colonizing stream fungi: comparison of macroinvertebrate taxa. Oecologia 79, 30-37, http://dx.doi.org/10.1007/BF00378236.

Assessment, M.E., 2005. Ecosystems and Human Well-being. Island Press, Washington, DC.

Baldwin, D.S., Wilson, J., Gigney, H., Boulding, A., 2010. Influence of extreme drawdown on water quality downstream of a large water storage reservoir. River Res. Appl. 26, 194-206, http://dx.doi.org/10.1002/rra.1255.

Bärlocher, F., Kendrick, B., 1975. Assimilation efficiency of Gammarus pseudolimnaeus (Amphipoda) feeding on fungal mycelium or autumn-shed leaves. Oikos, 55-59, http://dx.doi.org/10.2307/3543277.

Bärlocher, F., 1992. Research on aquatic hyphomycetes: historical background and overview. In: The Ecology of Aquatic Hyphomycetes. Springer, Berlin/Heidelberg, pp. 1-15, http://dx.doi.org/10.1007/978-3-642-76855-2_1.

Bärlocher, F., 2005. Freshwater fungal communities. In: The Fungal Community: its rganization and role in the ecosystem. CRC Press, Boca Raton, pp. 39-59.

Bärlocher, F., 2007. Molecular approaches applied to aquatic hyphomycetes. Fungal Biol. Rev. 21, 19-24, http://dx.doi.org/10.1016/j.fbr.2007.02.003. 
Bärlocher, F., 2009. Reproduction and dispersal in aquatic hyphomycetes. Mycoscience 50, 3-8, http://dx.doi.org/10.1007/s10267-008-0449-x.

Baudoin, J.-M., Guérold, F., Felten, V., Chauvet, E., Wagner, P., Rousselle, P., 2008. Elevated aluminium concentration in acidified headwater streams lowers aquatic hyphomycete diversity and impairs leaf-litter breakdown. Microb. Ecol. 56, 260-269, http://dx.doi.org/10.1007/s00248-007-9344-9.

Beasley, G., Kneale, P.E., 2004. Assessment of heavy metal and PAH contamination of urban streambed sediments on macroinvertebrates. Water Air Soil Pollut.: Focus 4, 563-578, http://dx.doi.org/10.1007/978-94-007-0952-2.38.

Birk, S., Bonne, W., Borja, A., Brucet, S., Courrat, A., Poikane, S., Solimini, A., Van de Bund, W., Zampoukas, N., Hering, D., 2012. Three hundred ways to assess Europe's surface waters: an almost complete overview of biological methods to implement the Water Framework Directive. Ecol. Indic. 18, 31-41, http://dx.doi. org/10.1016/j.ecolind.2011.10.009.

Borgmann, U., Norwood, W.P., Reynoldson, T.B., Rosa, F., 2001. Identifying cause in sediment assessments: bioavailability and the Sediment Quality Triad. Can. J. Fish. Aquat. Sci. 58, 950-960, http://dx.doi.org/10.1139/cjfas-58-5-950.

Bundschuh, M., Zubrod, J.P., Kosol, S., Maltby, L., Stang, C., Duester, L., Schulz, R., 2011. Fungal composition on leaves explains pollutant-mediated indirect effects on amphipod feeding. Aquat. Toxicol. 104, 32-37, http://dx.doi.org/10.1016/j. aquatox.2011.03.010.

Butchart, S.H., Walpole, M., Collen, B., Van Strien, A., Scharlemann, J.P., Almond, R.E., Baillie, J.E., Bomhard, B., Brown, C., Bruno, J., et al., 2010. Global biodiversity: indicators of recent declines. Science 328, 1164-1168, http://dx.doi.org/10.1126/ science. 1187512

Byrne, P., Reid, I., Wood, P.J., 2010. Sediment geochemistry of streams draining abandoned lead/zinc mines in central Wales: the Afon Twymyn. J. Soils Sediments 10, 683-697, http://dx.doi.org/10.1007/s11368-009-0183-9.

Calow, P., Forbes, V.E., 2003. Peer reviewed: does ecotoxicology inform ecological risk assessment? Environ. Sci. Technol. 37, 146A-151A, http://dx.doi.org/ 10.1021/es0324003.

Canhoto, C., Bärlocher, F., Graça, M.A.S., 2002. The effects of Eucalyptus globulus oils on fungal enzymatic activity. Arch. Hydrobiol. 154, 121-132.

Chessel, D., Dufour, A.B., Thioulouse, J., 2004. The ade4 package-I - one-table methods. R News 4, 5-10.

Chung, N., Suberkropp, K., 2009. Effects of aquatic fungi on feeding preferences and bioenergetics of Pycnopsyche gentilis (Trichoptera: Limnephilidae). Hydrobiologia 630, 257-269, http://dx.doi.org/10.1007/s10750-009-9820-y.

Clements, W.H., Carlisle, D.M., Courtney, L.A., Harrahy, E.A., 2002. Integrating observational and experimental approaches to demonstrate causation in stream biomonitoring studies. Environ. Toxicol. Chem. 21, 1138-1146, http://dx.doi. $\operatorname{org} / 10.2307 / 1467263$.

Clivot, H., Danger, M., Pagnout, C., Wagner, P., Rousselle, P., Poupin, P., Guérold, F., 2013. Impaired leaf litter processing in acidified streams. Microb. Ecol. 65, 1-11, http://dx.doi.org/10.1007/s00248-012-0107-x.

Colas, F., Archaimbault, V., Férard, J.-F., Bouquerel, J., Roger, M.-C., Devin, S., 2013a. Benthic indicators of sediment quality associated with run-of-river reservoirs. Hydrobiologia 703, 149-164, http://dx.doi.org/10.1007/s10750-0121355-y.

Colas, F., Baudoin, J.-M., Danger, M., Usseglio-Polatera, P., Wagner, P., Devin, S., 2013b. Synergistic impacts of sediment contamination and dam presence on river functioning. Freshw. Biol. 58, 320-336, http://dx.doi.org/10.1111/fwb. 12060.

Colas, F., Vigneron, A., Felten, V., Devin, S., 2014. The contribution of a nichebased approach to ecological risk assessment: using macroinvertebrate species under multiple stressors. Environ. Pollut. 185, 24-34, http://dx.doi.org/10.1016/ j.envpol.2013.09.033.

Covich, A.P., Austen, M.C., Bärlocher, F., Chauvet, E., Cardinale, B.J., Biles, C.L., Inchausti, P., Dangles, O., Solan, M., Gessner, M.O., 2004. The role of biodiversity in the functioning of freshwater and marine benthic ecosystems. BioScience 54, 767-775, http://dx.doi.org/10.1641/0006-3568(2004)054[0767:TR.

Dade, W.B., Renshaw, C.E., Magilligan, F.J., 2011. Sediment transport constraints on river response to regulation. Geomorphology 126, 245-251, http://dx.doi.org/ 10.1016/j.geomorph.2010.11.007.

Danger, M., Cornut, J., Elger, A., Chauvet, E., 2012. Effects of burial on leaf litter quality, microbial conditioning and palatability to three shredder taxa. Freshw. Biol. 57 1017-1030, http://dx.doi.org/10.1111/j.1365-2427.2012.02762.x.

Danger, M., Arce Funck, J., Devin, S., Heberle, J., Felten, V., 2013. Phosphorus content in detritus controls life-history traits of a detritivore. Funct. Ecol. 27, 807-815, http://dx.doi.org/10.1111/1365-2435.12079.

Dangles, O., Gessner, M.O., Guerold, F., Chauvet, E, 2004. Impacts of stream acidification on litter breakdown: implications for assessing ecosystem functioning. J. Appl. Ecol. 41, 365-378, http://dx.doi.org/10.1111/j.0021-8901.2004.00888.x.

Duarte, S., Pascoal, C., Alves, A., Correia, A., Cassio, F., 2008. Copper and zinc mixtures induce shifts in microbial communities and reduce leaf litter decomposition in streams. Freshw. Biol. 53, 91-101, http://dx.doi.org/10.1111/j.1365-2427.2007. 01869.x.

Dudgeon, D., 2010. Prospects for sustaining freshwater biodiversity in the 21st century: linking ecosystem structure and function. Curr. Opin. Environ. Sustain. 2. 422-430, http://dx.doi.org/10.1016/j.cosust.2010.09.001.

Elger, A., Lemoine, D., 2005. Determinants of macrophyte palatability to the pond snail Lymnaea stagnalis. Freshw. Biol. 50, 86-95, http://dx.doi.org/10.1111/j. 1365-2427.2004.01308.x.

Elosegi, A., Sabater, S., 2012. Effects of hydromorphological impacts on river ecosystem functioning: a review and suggestions for assessing ecological impacts. Hydrobiologia 712, 129-143, http://dx.doi.org/10.1007/s10750-012-1226-6.
Fernandes, I., Duarte, S., Cássio, F., Pascoal, C., 2009. Mixtures of zinc and phosphate affect leaf litter decomposition by aquatic fungi in streams. Sci. Total Environ. 407, 4283-4288, http://dx.doi.org/10.1016/j.scitotenv.2009.04.007.

Ferreira, V., Graça, M.A., 2006. Do invertebrate activity and current velocity affect fungal assemblage structure in leaves? Int. Rev. Hydrobiol. 91, 1-14, http://dx. doi.org/10.1002/iroh.200510833.

Findlay, S.E.G., Arsuffi, T.L., 1989. Microbial growth and detritus transformations during decomposition of leaf litter in a stream. Freshw. Biol. 21, 261-269, http:// dx.doi.org/10.1111/j.1365-2427.1989.tb01364.x.

Flores, L., Banjac, Z., Farré, M., Larrañaga, A., Mas-Martí, E., Muñoz, I., Barceló, D., Elosegi, A., 2014. Effects of a fungicide (imazalil) and an insecticide (diazinon) on stream fungi and invertebrates associated with litter breakdown. Sci. Total Environ. 476-477, 532-541, http://dx.doi.org/10.1016/j.scitotenv.2014.01.059.

Forbes, V.E., Calow, P., Sibly, R.M., 2001. Are current species extrapolation models a good basis for ecological risk assessment? Environ. Toxicol. Chem. 20, 442-447, http://dx.doi.org/10.1002/etc.5620200227.

Funck, J.A., Clivot, H., Felten, V., Rousselle, P., Guérold, F., Danger, M., 2013. Phosphorus availability modulates the toxic effect of silver on aquatic fungi and leaf litter decomposition. Aquat. Toxicol. 144-145, 199-207, http://dx.doi.org/10.1016/j. aquatox.2013.10.001.

Gessner, M.O., Chauvet, E., 1993. Ergosterol-to-biomass conversion factors for aquatic hyphomycetes. Appl. Environ. Microbiol., 502-507.

Gessner, M.O., Chauvet, E., 2002. A case for using litter breakdown to assess functional stream integrity. Ecol. Appl. 12, 498-510, http://dx.doi.org/10.1890/ 10510761(2002)012[0498:ACFULB]2.0.CO;2.

Gessner, M.O., Bärlocher, F., Chauvet, E., 2003. Qualitative and quantitative analyses of aquatic hyphomycetes in streams. Fungal Divers. Res. Ser. 10, $127-157$.

González, J.M., Mollá, S., Roblas, N., Descals, E., Moya, Ó., Casado, C., 2013. Small dams decrease leaf litter breakdown rates in Mediterranean mountain streams. Hydrobiologia 712, 117-128, http://dx.doi.org/10.1007/s10750-0121144-7.

Graça, M.A.S., Maltby, L., Calow, P., 1993. Importance of fungi in the diet of Gammarus pulex and Asellus aquaticus I: feeding strategies. Oecologia 93, 139-144, http:// dx.doi.org/10.1007/BF00321203.

Graça, M.A.S., Bärlocher, F., Gessner, M.O., 2005. Methods to Study Litter Decomposition: A Practical Guide. Springer.

Graça, M.A.S., Cressa, C., Gessner, T.M.O., Feio, M.J., Callies, K.A., Barrios, C., 2001. Food quality, feeding preferences, survival and growth of shredders from temperate and tropical streams. Freshw. Biol. 46, 947-957.

Greenwood, J.L., Rosemond, A.D., Wallace, J.B., Cross, W.F., Weyers, H.S., 2007. Nutrients stimulate leaf breakdown rates and detritivore biomass: bottom-up effects via heterotrophic pathways. Oecologia 151,637-649, http://dx.doi.org/10.1007/ s00442-006-0609-7.

Guisan, A., Zimmermann, N.E., 2000. Predictive habitat distribution models in ecology. Ecol. Modell. 135 (2), 147-186.

Hector, A., Schmid, B., Beierkuhnlein, C., Caldeira, M.C. Diemer, M., Dimitrakopoulos, P.G., Finn, J.A., Freitas, H., Giller, P.S., Good, J., et al., 1999. Plant diversity and productivity experiments in European grasslands. Science 286, 1123-1127, http://dx.doi.org/10.1126/science.286.5442.1123.

Hodgson, J.G., Thompson, K., Wilson, P.J., Bogaard, A., 1998. Does biodiversity determine ecosystem function? The Ecotron experiment reconsidered. Funct. Ecol. 12 (5), 843-848.

Hooper, D.U., Chapin Iii, F.S., Ewel, J.J., Hector, A., Inchausti, P., Lavorel, S., Lawton, J.H., Lodge, D.M., Loreau, M., Naeem, S., 2005. Effects of biodiversity on ecosystem functioning: a consensus of current knowledge. Ecol. Monogr. 75, 3-35, http:// dx.doi.org/10.1890/04-0922.

Hupfer, M., Lewandowski, J., 2008. Oxygen controls the phosphorus release from lake sediments - a long-lasting paradigm in limnology. Int. Rev. Hydrobiol. 93, 415-432, http://dx.doi.org/10.1002/iroh.200711054.

Krauss, G.J., Solé, M., Krauss, G., Schlosser, D., Wesenberg, D., Bärlocher, F., 2011. Fungi in freshwaters: ecology, physiology and biochemical potential. FEMS Microbiol. Rev. 35, 620-651, http://dx.doi.org/10.1111/j.1574-6976.2011. 00266.x.

Lafont, M., Grapentine, L., Rochfort, Q., Marsalek, J., Tixier, G., Breil, P., 2007. Bioassessment of wet-weather pollution impacts on fine sediments in urban waters by benthic indices and the sediment quality triad. Water Sci. Technol. 56,13 .

Laitung, B., Pretty, J.L., Chauvet, E., Dobson, M., 2002. Response of aquatic hyphomycete communities to enhanced stream retention in areas impacted by commercial forestry. Freshw. Biol. 47, 313-323, http://dx.doi.org/10.1046/ j.1365-2427.2002.00801.x.

Lecerf, A., Chauvet, E., 2008. Diversity and functions of leaf-decaying fungi in humanaltered streams. Freshw. Biol. 53, 1658-1672, http://dx.doi.org/10.1111/j.13652427.2008.01986.x.

Loreau, M., Naeem, S., Inchausti, P., et al., 2002. Biodiversity and Ecosystem Functioning: Synthesis and Perspectives. Oxford University Press.

Maltby, L., 1999. Studying stress: the importance of organism-level responses. Ecol. Appl. 9, 431-440, http://dx.doi.org/10.2307/2641131.

Medeiros, A., Duarte, S., Pascoal, C., Cássio, F., Graça, M.A.S., 2010. Effects of Zn, Fe and $\mathrm{Mn}$ on leaf litter breakdown by aquatic fungi: a microcosm study. Int. Rev. Hydrobiol. 95, 12-26, http://dx.doi.org/10.1002/iroh.200911182.

Mendoza-Lera, C., Larrañaga, A., Pérez, J., Descals, E., Martínez, A., Moya, O., Arostegui, I., Pozo, J., 2012. Headwater reservoirs weaken terrestrial-aquatic linkage by slowing leaf-litter processing in downstream regulated reaches. River Res. Appl. 28, 13-22, http://dx.doi.org/10.1002/rra.1434. 
Menéndez, M., Descals, E., Riera, T., Moya, O., 2012. Effect of small reservoirs on leaf litter decomposition in Mediterranean headwater streams. Hydrobiologia 691 135-146, http://dx.doi.org/10.1007/s10750-012-1064-6.

Miersch, J., Tschimedbalshir, M., Bärlocher, F., Grams, Y., Pierau, B., Schierhorn, A. Krauss, G.-J., 2001. Heavy metals and thiol compounds in Mucor racemosus and Articulospora tetracladia. Mycol. Res. 105, 883-889, http://dx.doi.org/10.1017/ S095375620100404X.

Mineau, M.M., Fatemi, F.R., Fernandez, I.J., Simon, K.S., 2013. Microbial enzyme activity at the watershed scale: response to chronic nitrogen deposition and acute phosphorus enrichment. Biogeochemistry 117, 131-142, http://dx.doi.org/10. 1007/s10533-013-9869-6.

Muehlbauer, J.D., LeRoy, C.J., Lovett, J.M., Flaccus, K.K., Vlieg, J.K., Marks, J.C., 2009 Short-term responses of decomposers to flow restoration in Fossil Creek, Arizona, USA. Hydrobiologia 618, 35-45, http://dx.doi.org/10.1007/s10750-0089545-3.

Navel, S., Mermillod-Blondin, F., Montuelle, B., Chauvet, E., Marmonier, P., 2012. Sedimentary context controls the influence of ecosystem engineering by bioturbators on microbial processes in river sediments. Oikos 121, 1134-1144, http:/| dx.doi.org/10.1111/j.1600-0706.2011.19742x.

Neal, C., Whitehead, P.G., Jeffery, H., Neal, M., 2005. The water quality of the River Carnon, west Cornwall, November 1992 to March 1994: the impacts of Wheal Jane discharges. Sci. Total Environ. 338, 23-39, http://dx.doi.org/10.1016 j.scitotenv.2004.09.003.

Nikolcheva, L.G., Cockshutt, A.M., Bärlocher, F., 2003. Determining diversity of freshwater fungi on decaying leaves: comparison of traditional and molecular approaches. Appl. Environ. Microbiol. 69, 2548-2554.

Nikolcheva, L.G., Bärlocher, F., 2004. Taxon-specific fungal primers reveal unexpectedly high diversity during leaf decomposition in a stream. Mycol. Prog. 3, 41-49, http://dx.doi.org/10.1007/s11557-006-0075-y.

Nikolcheva, L.G., Bärlocher, F., 2005. Seasonal and substrate preferences of fungi colonizing leaves in streams: traditional versus molecular evidence. Environ Microbiol. 7, 270-280, http://dx.doi.org/10.1111/j.1462-2920.2004.00709.x.

Nilsson, C., Reidy, C.A., Dynesius, M., Revenga, C., 2005. Fragmentation and flow regulation of the world's large river systems. Science 308, 405-408.

Niyogi, D.K., McKnight, D.M., Lewis Jr., W.M., 2002. Fungal communities and biomass in mountain streams affected by mine drainage. Arch. Hydrobiol. 155, 255-271.

Palmer, M.A., Febria, C.M., 2012. The heartbeat of ecosystems. Science 336 1393-1394, http://dx.doi.org/10.1126/science.1223250.

Pascoal, C., Cássio, F., Marvanová, L., 2005. Anthropogenic stress may affect aquatic hyphomycete diversity more than leaf decomposition in a low-order stream. Arch. Hydrobiol. 162, 481-496, http://dx.doi.org/10.1127/0003-9136 2005/0162-0481.

Petts, G.E., 1989. Perspectives for ecological management of regulated rivers. Altern. Regul. River Manag., 3-24.

Proia, L., Cassió, F., Pascoal, C., Tlili, A., Romaní, A.M., 2012. The use of attached microbial communities to assess ecological risks of pollutants in river ecosystems: the role of heterotrophs. In: Emerging and Priority Pollutants in Rivers, The Handbook of Environmental Chemistry. Springer, Berlin/Heidelberg, pp. 55-83.

R Development Core Team, 2008. R: A Language and Environment for Statistical Computing. R Foundation for Statistical Computing, Vienna, Austria.

Rounick, J.S., Winterbourn, M.J., 1983. Leaf processing in two contrasting beech forest streams: effects of physical and biotic factors on litter breakdown. Arch. Hydrobiol. 96, 448-474.

Rubach, M.N., Ashauer, R., Buchwalter, D.B., De Lange, H.J., Hamer, M., Preuss, T.G. Töpke, K., Maund, S.J., 2011. Framework for traits-based assessment in ecotoxicology. Integr. Environ. Assess. Manag. 7, 172-186, http://dx.doi.org/10.1002/ ieam.105.
Sandin, L., Solimini, A.G., 2009. Freshwater ecosystem structure-function relationships: from theory to application. Freshw. Biol. 54, 2017-2024, http://dx.doi. org/10.1111/j.1365-2427.2009.02313.

Schlief, J., Mutz, M., 2011. Leaf decay processes during and after a supra-seasonal hydrological drought in a temperate lowland stream. Int. Rev. Hydrobiol. 96, 633-655, http://dx.doi.org/10.1002/iroh.201111322.

Schlief, J., Mutz, M., 2009. Effect of sudden flow reduction on the decomposition of alder leaves (Alnus glutinosa [L.] Gaertn.) in a temperate lowland stream: a mesocosm study. Hydrobiologia 624, 205-217, http://dx.doi.org/10.1007/s10750008-9694-4.

Schwartz, M.W., Brigham, C.A., Hoeksema, J.D., Lyons, K.G., Mills, M.H., Van Mantgem, P.J., 2000. Linking biodiversity to ecosystem function: implications for conservation ecology. Oecologia 122, 297-305, http://dx.doi.org/10.1007/ s004420050035.

Solé, M., Fetzer, I., Wennrich, R., Sridhar, K.R., Harms, H., Krauss, G., 2008. Aquatic hyphomycete communities as potential bioindicators for assessing anthropogenic stress. Sci. Total Environ. 389, 557-565, http://dx.doi.org/10.1016/j. scitotenv.2007.09.010.

Sorensen, M.T., Conder, J.M., Fuchsman, P.C., Martello, L.B., Wenning, R.J., 2007. Using a sediment quality triad approach to evaluate benthic toxicity in the lower Hackensack River, New Jersey. Arch. Environ. Contam. Toxicol. 53, 36-49, http://dx. doi.org/10.1007/s00244-006-0165-5.

Suberkropp, K., 1992. Interactions with invertebrates. In: The Ecology of Aquatic Hyphomycetes. Springer, Berlin/Heidelberg, pp. 118-134.

Suberkropp, K., 1998. Microorganisms and organic matter processing. In: River Ecology and Management: Lessons from the Pacific Coastal Ecoregion. Springer, Berlin/Heidelberg, pp. 120-143.

Tilman, D., Reich, P.B., Knops, J., Wedin, D., Mielke, T., Lehman, C., 2001. Diversity and productivity in a long-term grassland experiment. Science 294, 843-845, http://dx.doi.org/10.1126/science.1060391.

Vitousek, P.M., Mooney, H.A., Lubchenco, J., Melillo, J.M., 1997. Human domination of Earth's ecosystems. Science 277, 494-499, http://dx.doi.org/10.1126/science. 277.5325.494.

Vörösmarty, C.J., Meybeck, M., Fekete, B., Sharma, K., Green, P., Syvitski, J.P., 2003. Anthropogenic sediment retention: major global impact from registered river impoundments. Glob. Planet. Change 39, 169-190, http://dx.doi.org/10.1016/ S0921-8181(03)00023-7.

Walsh, C., MacNally, R., 2004. Hierarchical partitioning. In: The R Project for Statistical Computing.

Weyers, H.S., Suberkropp, K., 1996. Fungal and bacterial production during the breakdown of yellow poplar leaves in 2 streams. J. N. Am. Benthol. Soc., 408-420, http://dx.doi.org/10.2307/1467795.

Woodward, G., Gessner, M.O., Giller, P.S., Gulis, V., Hladyz, S., Lecerf, A., Malmqvist, B., McKie, B.G., Tiegs, S.D., Cariss, H., 2012. Continental-scale effects of nutrient pollution on stream ecosystem functioning. Science 336, 1438-1440, http://dx. doi.org/10.1126/science.1219534.

Young, R.G., Matthaei, C.D., Townsend, C.R., 2008. Organic matter breakdown and ecosystem metabolism: functional indicators for assessing river ecosystem health. J. N. Am. Benthol. Soc. 27, 605-625, http://dx.doi.org/10.1899/07-121. 1.

Zak, D.R., Holmes, W.E., White, D.C., Peacock, A.D., Tilman, D., 2003. Plant diversity, soil microbial communities, and ecosystem function: are there any links? Ecology 84, 2042-2050, http://dx.doi.org/10.1890/02-0433.

Zubrod, J.P., Bundschuh, M., Schulz, R., 2010. Effects of subchronic fungicide exposure on the energy processing of Gammarus fossarum (Crustacea; Amphipoda). Ecotoxicol. Environ. Saf. 73, 1674-1680, http://dx.doi.org/10.1016/j.ecoenv.2010. 07.046. 